\title{
The logic behind foreign market selection: \\ Objective distance dimensions vs. strategic objectives and psychic distance
}

\begin{abstract}
The aim of this paper is to highlight the importance of the firm's strategic objectives regarding the choice of countries for foreign expansion, complementing the existing literature on the internationalisation process. Through a multiple case study methodology, we conduct a comparative analysis of three Brazilian ventures that have internationalised in Italy, and three Italian firms that have internationalised in Brazil, seeking to investigate the firms' decisions on the selection of foreign markets. We consider jointly the objective aspects of distance, the overall perceptions of the decision-makers in relation to the differences between the domestic and (potential) host countries, and the firm's strategic objectives. This research contributes to International Business studies by revealing the role of firm-specific strategic objectives as determinants of foreign market selection, in addition to, or even on top of, the dimensions of objective distance and psychic distance.
\end{abstract}

Paper type - Research paper.

Keywords: distance; asymmetry; relativity; strategic objectives; foreign market selection; multiple case study. 


\section{INTRODUCTION}

The choice of foreign markets is a key issue in the International Business (IB) literature, which has traditionally approached it through the lens of what Hymer terms the "liability of foreignness" (Hymer, 1976). From this perspective, the so-called Uppsala model of international growth posits that due to risk aversion and a lack of knowledge about foreign markets, the choice of a foreign country depends on psychic distance (Johanson \& Vahlne, 1977). This approach has been criticized in the following years for its determinism (Andersen, 1997; Melin, 1992; Petersen et al, 2003). The International Entrepreneurship (IE) stream of research states that firms can target "distant" markets from their beginning, mostly leveraging the experience and network of their key decision makers (e.g. Oviatt \& McDougall, 1994; Zahra, Matherne, \& Carleton, 2003). Both streams suffer determinism and path dependence to some extent, which seems also confirmed in the recent version of the Uppsala model (Johanson \& Vahlne, 2009). Autio (2017, p. 38) recently argued: “The network perspective to internationalization originally built upon the Uppsala portrayal and shares many ontological features and elements of theoretical logic [...]. In the network ontology, similar to the process ontology, there appear to be few shortcuts to overcome the liabilities of foreignness and outsidership.”.

What leads a firm to choose to enter a distant market, without any prior experience in the organization or decision-makers of that market, and without any existing partnership? We still have no adequate answer to this question, which refers to the actual behaviour of a number of firms that are internationalising. We believe that managerial discretion (Petersen et al, 2003) and the strategies they implement in their organizations can shed light on this question, and that the "strategic objectives explanation" can fruitfully complement the existing knowledge about foreign market selection. In adopting this perspective, we respond to a call for contributions dating back to Melin (1992), who asked researchers to include strategy among the key variables in their multinational enterprises (MNEs) studies, and Bell 
et al (2004), who invited researchers to include strategy as a determinant in the international growth of small and medium enterprises (SMEs). Chetty \& Campbell-Hunt (2004) discussed strategy as a strong motivator for international growth, both for born globals and for established firms. These calls for studies are also recently supported by Terjesen, Hessels \& Li (2016), Love \& Roper (2015) and Benito (2015), who highlights that a firms' internationalisation is purposeful and goal-oriented: "Without an explicit and clear notion of motives, conceptualizations of firms' internationalisation are bound to be imprecise [...] which $[\ldots]$ has been the case for the well-known internationalisation process model." (ibid, p. 16).

Strategic objectives may lead a firm to enter markets characterised by high distance, thus bridging the known with the unknown, and can provide a motive to face the liability of foreignness.

But what exactly is distance? This construct is at the heart of IB studies, and has received much attention from scholars in the field. Distance encompasses many different dimensions, including geographical, cultural, administrative, and economic distance (Ghemawat, 2001). It can be approached (and measured) as an objective variable, but it can also be viewed as a matter of decision makers' perceptions (psychic distance, Johanson \& Vahlne, 1977), affected by their knowledge and previous experience in foreign markets. Moreover, distance can be viewed as either symmetrical or asymmetrical (Beugelsdijk \& Mudambi, 2013; Håkanson \& Ambos, 2010; Håkanson et al, 2016; Shenkar, Luo, \& Yeheskel, 2008, Tung \& Verbeke, 2010; Zaheer, Schomaker, \& Nachum, 2012), as either absolute or relative (Beugelsdijk \& Mudambi, 2013; Goerzen, Asmussen, \& Nielsen, 2013; Håkanson \& Ambos, 2010;).

Asymmetry occurs when the distance between A and B is different (or is perceived differently) from the distance between B and A. It explains why, when it comes to the 
distance between country A and country B, decision-makers in country A perceive the distance between themselves and B differently from the way decisions-makers in country B perceive the distance between themselves and A.

Relativity, on the other hand, occurs when different decision-makers in country A experience and perceive the distance from country B differently, due to industry and productspecific motivations, for example (Ghemawat, 2001).

We contend that strategic objectives represent an important determinant of both distance asymmetry and distance relativity, in addition to objective and perceptual causes.

Our empirical context encompasses the internationalisation decisions of Brazilian and Italian firms that have internationalised in Italy and Brazil, respectively. We chose to study firms from a pair of countries, as recommended in the most recent literature (Puthusserry, Child \& Rodrigues, 2014) and, in order to extend the understanding of the mechanisms behind Internationalisation decisions, we analyzed the different dimensions of distance in conjunction (Ambos \& Håkanson; 2014; Ojala, 2015; Williams \& Grégoire, 2014). By studying firms from a pair of countries, we also can better explore the asymmetry and relativity issues related to distance. This study therefore contributes to understanding the internationalisation process of firms in a globalized era, in which distances are increasingly showing traits of relativity and asymmetry in an "intercontextual business" (Knight \& Liesch, 2016) environment. This work contributes to IB and IE studies by highlighting the critical role of strategic objectives in foreign market selection, in addition to the already acknowledged roles of objective distance dimensions, and how they are perceived by decision-makers (i.e. psychic distance).

The reminder of the paper is structured as follows. After describing our theoretical framework, we present the methodological component, which includes a comparison of Brazil and Italy in terms of classical IB objective dimensions of distance, and international business 
activity between the two. Subsequently, building on evidence from the case studies, we illustrate and discuss these findings, offering a set of propositions and a model. Finally, we highlight our contributions to the literature on IB and IE, and provide some insights for management practice.

\section{THEORETICAL FRAMEWORK}

\subsection{Dimensions of distance, perceptions of distance, and strategic objectives in foreign market selection}

The construct of distance has multiple dimensions (geographic, cultural and institutional, economic), which can be approached and measured adopting an objective perspective (how distant is country A from country B in terms of kilometres, institutions, markets, etc.) or through the subjective point of view of decision makers (psychic distance).

Economic distance refers to country differences in consumer wealth or income (Ghemawat, 2011), but also encompasses differences in customer preferences and purchasing power (Hutzschenreuter et al, 2016), which, taken together, provide insights into the country's market potential. Economic distance is usually measured using objective indicators such as income (GDP per capita); inflation (GDP deflator); exports of goods and services, and imports of goods and services (as \% of GDP) (see Ellis, 2008, for example). At present, only a few studies have investigated in-depth the effects of economic distance with respect to foreign market selection (Hutzschenreuter et al, 2016).

Geographic distance is often measured as the spatial distance between the centres of a pair of countries (Berry, Guillén, \& Zhou, 2010) or as the distance between their capital cities (Campbell, Eden, \& Miller, 2012; Slangen \& Beugelsdijk, 2010). It has been argued that geographic distance is a barrier to international trade (Frankel \& Rose, 2002; Hummels, 2001; Leamer, 1974; Limao \& Venables, 2001), on the basis that a greater distance, will result in higher transportation costs (Clark, Dollar \& Micco, 2004; Combes \& Lafourcade, 2005; 
Hummels, 2001; Leamer, 1974), more difficulties monitoring markets and the firm's activities abroad (Grant, 1987), and barriers to interactions (Bell \& Kozlowski, 2002; Hinds \& Bailey, 2003), ultimately inhibiting the decision to enter a geographically distant target country. For instance, Hummels (2001) quantified transport costs by estimating that every additional day of ocean transit reduces the probability of trade between two countries by $1.5 \%$ for manufactured goods.

Institutional distance refers to the extent to which the institutional profiles of two countries differ (Ferner, Almond, \& Colling, 2005). It has been shown to influence bilateral business relationships (Eden \& Miller, 2004; Puthusserry et al, 2014; Verwaal \& Donkers, 2003), performance (Chao \& Kumar, 2010), and entry mode decisions (Meyer, Estrin, Bhaumik, \& Peng, 2009). Institutional distance may also include aspects of administrative distance (Ghemawat, 2001) i.e. the extent to which local governments raise barriers to foreign competition (ibid), the legal framework and its enforcement, property rights, information systems, and regulatory regimes. These aspects also affect decisions on the mode of entry (Meyer et al, 2009), as they impact on the attractiveness of a given location. Kaufmann, Kraay, \& Mastruzzi (2009) offer a set of "objective" indicators to measure institutional distance according to six different dimensions of governance: control of corruption; rule of law; voice and accountability; government effectiveness; political stability; and regulatory quality.

Cultural distance refers to differences in the "system of collectively held values" (Hofstede, 1980, p. 9), as well as communication styles, and stereotypes (Ojala, 2015). The four cultural attributes proposed by Hofstede (1980) are used extensively in the literature. Cultural distance is also often understood at the country level of analysis (see Ghemawat, 2001 and Hofstede, 1980, for example) and discussion focuses mainly on how countryspecific cultural traits affect the ability of the business to penetrate a culturally diverse context 
(Yamin \& Sinkovics 2006; Zaheer, 1995). Culture is often measured using the Kogut \& Singh (1988) index. According to Ellis (2008), although it is acknowledged that the Kogut \& Singh index has some flaws (Dow \& Karunaratna 2006; Shenkar, 2001), it is still widely used by many studies on cultural distance (Dow, 2000; Sousa \& Bradley, 2006).

Overall, studies have reported mixed results in relation to the effects of cultural distance. Some found that the cultural environment of a target country was the least important factor affecting a firm's decision-making (e.g. Robertson \& Wood, 2001), while others concluded that it was the most important one (e.g. Edwards \& Buckley, 1998). As far as geographic distance is concerned, the findings of Ellis (2007) on the perceived effects of geography are mixed. Neither it is clear whether, and to what extent firm-specific characteristics (Ojala, 2015) can influence geographic distance.

These controversial findings are attributable - among other factors - to the fact that distance can be asymmetric and relative (Beugelsdijk \& Mudambi, 2013). For example, the objective measures of geographic distance that have been mentioned do not take into consideration the effects of several important firm-level elements. The impact of geographic distance is very much affected by differences in transport costs, which, in turn, are specific to the products a firm needs to transport (Beugelsdijk \& Mudambi, 2013; Nebus \& Chai, 2014), by a firms' specific value chain (Cantwell \& Mudambi, 2005; Schmitt \& Van Biesebroeck, 2013) and/or by its strategic objectives (Beugelsdijk \& Mudambi, 2013). The same holds for the other dimensions of distance.

The different dimensions of distance can be approached from the lenses of objective measures, of the individual decision makers' perceptions, and of firm-specific factors, primarily the strategic objectives of the firm. The three perspectives are complementary, but much remains to be said about their interrelations in driving the decision to choose a foreign market and particularly, how strategic objectives can offset the high distances perceived. 
When considering the perceptual facet of distance, we refer to psychic distance, defined as the manager's perceptions of environmental factors that are believed to influence her/his decisions (Nebus \& Chai, 2014). As such, psychic distance is conceived in a subjective manner and encompasses managerial cognition and perception (see Evans \& Mavondo, 2002) of country specific diversities. Psychic distance is at the heart of the gradual internationalisation process model (Johanson \& Vahlne, 1977): decision makers are risk averse, driven by experiential learning, and enter foreign markets gradually, starting with those which are psychically closer.

In the empirical literature, measures of psychic distance have also frequently adopted the Kogut \& Singh (1988) index or an adapted version of it, as a measure of cultural distance (e.g. Grosse \& Trevino, 1996; Morosini, Shane, \& Singh, 1998; Brouthers \& Brouthers, 2001; Manev \& Stevenson, 2001). As a result, psychic distance has often been equated with cultural distance (Kirkman, Lowe, \& Gibson, 2006; Håkanson \& Ambos, 2010) creating a great deal of confusion. However, the most important aspect of the concept of psychic distance is that it adds another perspective of measuring distance by introducing the individual perceptions of the different dimensions of distance.

Since psychic distance is concerned with individual perceptions, it incorporates elements of both relativity and asymmetry. Cultural, economic, geographic and institutional distance can be perceived differently by different individuals from the same country (relativity). Languages, institutions, political systems and cultural norms are psychic distance stimuli (Dow \& Karunaratna, 2006; Dow \& Larimo, 2009; Drogendijk \& Martín, 2015; Hutzschenreuter, Kleindienst, \& Lange, 2014) and are interpreted and perceived differently by different decision makers.

When looking at country pairs, studies have repeatedly found evidence of asymmetrical psychic distance (Dichtl, Leibold, Köglmayr, \& Mueller, 1984; Dow, 2000; 
Ellis, 2007; Brock, Shenkar, Shoham, \& Siscovick, 2008; Child, Rodrigues, \& Frynas, 2009; Håkanson \& Ambos, 2010; Puthusserry, Child, \& Rodrigues, 2014; Tung \& Verbeke, 2010; Yildiz, 2014).

Though psychic distance is a very relevant construct for understanding internationalisation, it is not immune from criticism. A number of empirical studies found that different firms exhibit different behaviours (see Black \& Mendenhall, 1991; Erramilli, 1991) and argued that paths to international growth may be "nonlinear" and "not incremental" as they may be subject to set-backs, leaps, and larger steps (Barkema \& Drogendijk, 2007; Garnsey, Stam \& Heffernan, 2006) due to firm-specific strategy affecting the course of internationalisation. We mentioned earlier how the Uppsala model has been criticised for its determinism (Petersen et al, 2003). However, Johanson \& Vahlne (1990), in addressing some criticisms of their original model (Johanson \& Vahlne, 1977), confirm that "The internationalisation process, once started, will tend to proceed regardless of whether strategic decisions in that direction are made or not" (ibid, p.12). In their 2009 contribution, which provides a revised version of their model, the Authors refer to the previous experience (of either the firms or its decision makers) and to their existing networks as the key variables affecting distance perceptions and thus market selection, further supporting a deterministic stance.

The IE literature, in providing a different explanation about the process of internationalisation, has not yet sufficiently taken into account the role of a firm's volition and strategic objectives (Bell et al, 2004; Love \& Roper, 2015; Terjesen, Hessels \& Li, 2016; Autio, 2017). While we know why some firms can enter distant markets (for example, thanks to the previous experience and existing networks of funders and managers), we do not have a sufficient understanding of why other firms do the same without the mentioned pre-requisites. 
The question of why a firm targets a particular distant market, among others, and in the absence of the above-mentioned enabling conditions, has yet to be fully answered.

In this study, we take into consideration the specific strategic objectives of firms, and how they affect foreign market selection, despite the objective and perceived high distance between the home and the target countries. In our opinion, firm-level factors, such as the nature of a firm's business and its strategic objectives, constitute an additional and very relevant piece in the puzzle of target country selection and internationalisation process.

While on one hand, country-specific (objective) characteristics and managers' (subjective) perceptions of them are relevant to the decision to enter a country, on the other hand, it is also true that the firm's volition, driven by strategic objectives, plays an important role in foreign market selection. Firms can expect higher returns from venturing into more distant countries, especially if the latter are "strategically important" (Zucchella \& Servais, 2012; D’Angelo et al, 2013).

The perspective of strategic objectives is thus linked to the factors of attractiveness of a foreign country for a given firm: firms seek an alignment between their objectives and the opportunities they envisage in foreign markets (Cui et al, 2014). Ceteris paribus, according to the literature on FDIs, the most important factor in the decision to enter a foreign market is the economic attractiveness of the country (see Mitra \& Golder, 2002). Economic attractiveness is related to factors such as, inter alia, market potential, growth, size (ibid). Of the many host country factors, market potential is widely considered as one of the most important variables in foreign market evaluation (see Malhotra, Sivakumar \& Zhu, 2009). Factors related to demand may also affect a market's attractiveness, for instance the overall fit of consumer demand with the firm's existing offer (Sakarya, Eckman \& Hyllegard, 2006).

In terms of strategic objectives, Van Tulder (2015) identifies three groups of motives for foreign direct investments (FDIs): intrinsic, extrinsic, and mixed motives. Intrinsic 
motives include classical Dunning's (1998) motives i.e. market-seeking, efficiency-seeking, resource-seeking, (strategic) asset-seeking. Extrinsic motives refer to "escape" motives from the home country; strategic extension of the home country, and high/low barriers to entry in the host country. Mixed strategic objectives refer to the sector-specific dynamics of internationalisation. Among these motives, Meyer (2015) stresses the importance of the "strategic-asset seeking" category which, according to the Author, should include "knowledge seeking" and "asset/resource augmenting" motives.

Firm-specific reasons can legitimize the decision to enter a market they see as attractive (Chandler \& Hanks, 1994), and which is instrumental to pursue the firm's specific strategic objectives. Focusing on the decision-maker and its role in foreign market selection, and jointly considering economic-driven and psychology-driven managerial motivations, Cuervo-Cazurra, Narula, \& Un (2015, p. 26) advance a set of strategic motives for foreign market expansion of MNEs which we shall also consider in our cross-case comparison, viz.: i. sell more (the firm exploits existing resources and obtains better host country conditions); ii. buy better (the company exploits existing resources and avoids poor home country conditions); iii. upgrade (the firm aims at developing new resources and access better host country conditions); and iv. escape (the firm explores new resources and avoids poor home country conditions).

How are all these motivations related to perceptions of distance? What drives the final decision to enter a (distant) foreign market?

Notwithstanding the abovementioned studies on the motivations to internationalise, and the repeated calls for research contributions on the role of strategy in internationalisation decisions (Bell, 2004; Benito, 2015; Love \& Roper, 2015; Melin, 1992), the link between managerial perceptions of distance, foreign market selection, and strategic objectives constitutes a gap in IB and IE studies. 


\section{RESEARCH CONTEXT}

\subsection{Italy and Brazil: Preliminary country comparison according to "objective" dimensions of distance}

Our context of analysis is internationalisation by Brazilian firms in Italy and by Italian firms in Brazil. This is a rich setting for investigating and generating insights on perceptions of distance and strategic decisions, for a number of reasons, which are discussed below.

Brazilian internationalisation in Europe is an under-studied topic in the literature. Much more attention has been devoted to analysing the behaviour and internationalisation patterns of Asian firms. This relative neglect is despite the fact that Brazil is a major economic player on the global stage. According to the World Bank (2016) GDP rankings, in 2015 Brazil was the ninth largest economy in the world. Notwithstanding a recent economic crisis, according to the 2015 UNCTAD World Investment Report, Brazil was still fourth in the ranking of the world's leading destinations for FDI inflows in 2014. Although the first moves to internationalise started back in the 1970s, it is only recently that Brazilian companies have engaged in substantial investment operations abroad (Fleury \& Fleury, 2011).

Italy is the eighth largest economy in the World (World Bank, 2016). Additionally, Italy ranks $11^{\text {th }}$ in the top 20 host economies for FDI inflows (UNCTAD, 2015) and is the fourth largest EU investor in transition economies (ibid).

There is considerable trade between Italy and Brazil. From 2003 to 2012, trade between the two countries increased by $170 \%$, reaching 8 billion dollars, with a surplus in the balance of payments for Italy of 1.6 billion dollars (ICE, 2013). Italian exports to Brazil grew by the $265 \%$ in that same period, driving Italian companies to achieve a $2.8 \%$ share of the Brazilian internal market (ICE, 2014). In 2012, Italian FDI flows to Brazil were $116 \%$ up on 2011, rising from 457 million to 986 million dollars (KPMG, 2013). According to recent statistics (Eurostat, 2016), Italy is Brazil's $9^{\text {th }}$ ranked trading partner. 
A further reason for studying these two countries is that they are geographically distant as well as distant in terms of institutional/administrative and economic characteristics (see Table 1). Evidence of institutional distance is seen, for instance, in the differences between the two countries' performances in control of corruption; rule of law; voice and accountability; government effectiveness; political stability; and regulatory quality (Kaufmann et al, 2009). In turn, the economic distance between them is manifest in the differences in income figures: notwithstanding the aforementioned high GDP growth rates, Brazil's per capita GDP is still only one third that of Italy (World Bank, 2015a, 2015b). Regarding cultural distance, according to Hofstede (1983) - Italy and Brazil are both characterized by a large power distance and strong uncertainty avoidance, but differ in the other dimensions. The calculation of the Kogut \& Singh's (1988) index -based on Hofstede's four cultural dimensions - resulted in a score of 1,105, showing that Italy and Brazil are neither culturally close, nor culturally distant (hypothesizing score ranges between $0.1-0.8$ for culturally close countries, and between $2-5$ for culturally distant ones, see Erikkson et al, 2000). Overall, the application of "objective" measures of different dimensions of distance suggests that the distance between Italy and Brazil is relatively high.

Table 1. Italy and Brazil: Comparison of countries by dimensions of distance, as measured by objective indices 


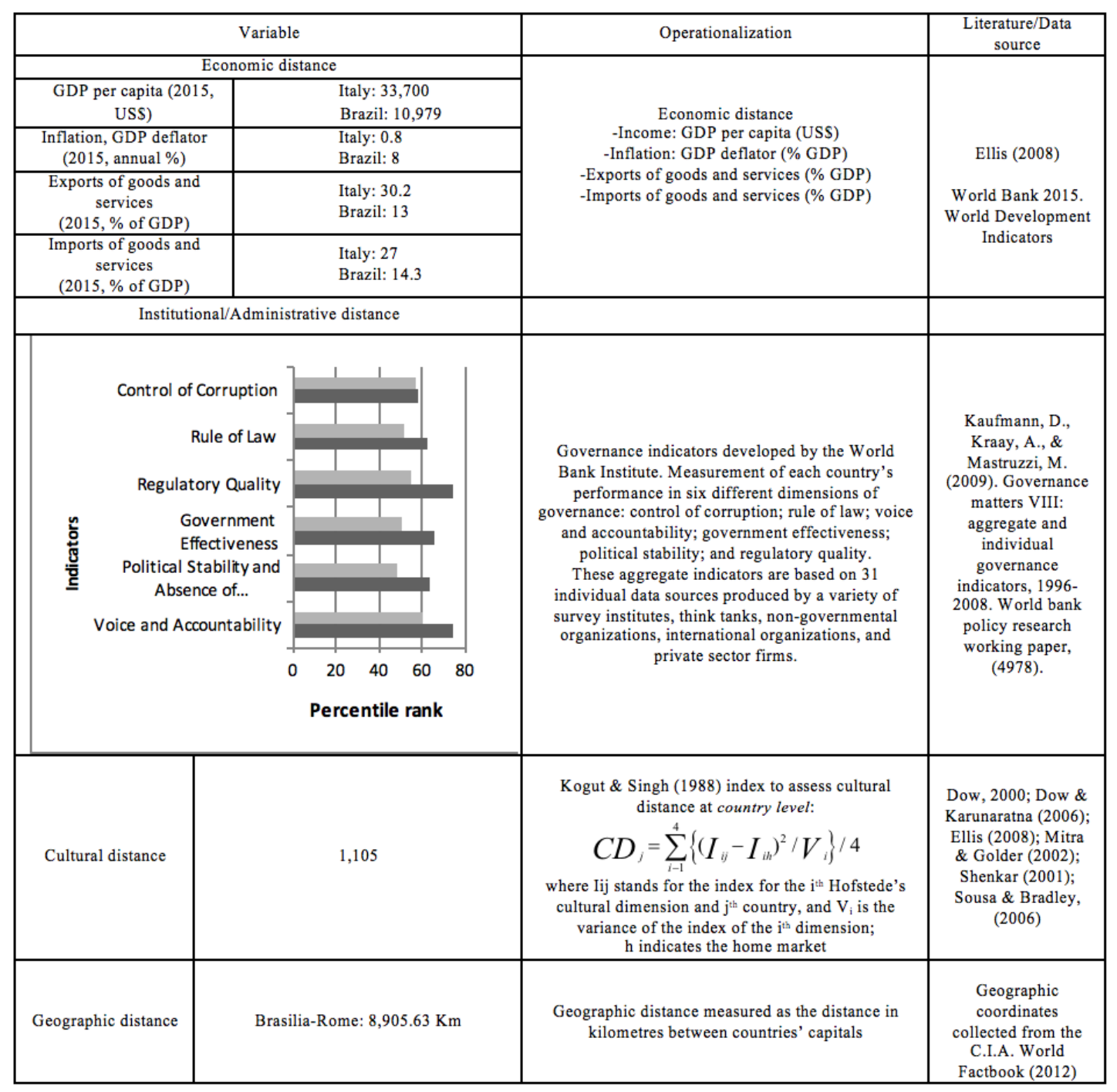

\section{EMPIRICAL WORK}

\subsection{Aim and selection of case studies}

The motivation for our empirical work is to investigate the role of strategic objectives in the decision to enter a foreign market, in conjunction with and beyond the role of the psychic distance perceived. Accordingly, we supplement our preliminary analysis of objective dimensions of distance between Brazil and Italy with data collection and analysis focusing on how our informants perceive the various dimensions of distance: cultural, institutional, geographic, and economic. We then expand our scope by considering firm-specific strategic objectives. 
Given the paucity of previous research, we chose an inductive, qualitative, and exploratory approach as most suitable to our objective. We employ the technique of building theory from multiple case studies (Eisenhardt, 1989; Eisenhardt \& Graebner, 2007; Ghauri \& Grønhaug, 2002; Ghauri, 2004), which we achieve by analysing multiple single cases and cross comparing them to identify recurrent patterns. The ultimate objective of our analyses is to advance "substantive theory" (Burgelman, 2011), i.e. theory which is not yet formal, but contingent to a specific context, and preliminary to the development of formal theory (Glaser \& Strauss, 1967).

The unit of analysis of the empirical investigation is the foreign market selection decision. The sources of evidence are knowledgeable informants (see section 4.2) who were fully responsible for taking internationalisation decisions and who therefore - via their intentionality - could direct their firms' internationalisation. In our data analysis, we thus report our informants' perceptions of distance in conjunction with firm-specific internationalisation strategic objectives, as described during interviews and triangulated with secondary data sources such as company reports (see section 4.2).

Our case selection is based on purposive sampling criteria (Patton, 1990). The first criterion is geographical: we first needed to look for Brazilian and Italian firms internationalised in Italy and Brazil respectively, because we valued this research context rich and insightful for our research aim. As described in section 3.1., Italy and Brazil are "distant" countries when measured by geographical distance. We identified a set of Italian and Brazilian firms during a previous quantitative study involving questionnaires. These firms differed in terms of their age, size and the sectors in which they do business, ranging from manufacturing to services. The second criterion was based on the availability of informants: we contacted the pool of identified firms and asked them whether they would be willing to participate in in-depth interviews (see Table 2). We matched the available firms with a third 
criterion, based on convenience: they had to be also physically accessible, i.e. located relatively close to the investigators (specifically, to the researcher based in Brazil, and to the two researchers based in Italy). We thus found six firms (three Italian and three Brazilian) with operations in Brazil and Italy respectively, and from different industries, in order to control for possible industry-specific factors.

Our firms belong either to traditional industries, such as garments or wine, or to specialisation industries, such as machinery or components for dental care. Finally, the 7Pixel case is interesting as it offers insights into a young, hi-tech firm in a highly innovative and fast-moving sector. The sampled firms are also heterogeneous in terms of age and international experience.

Overall, the analysis of our case studies adopts a replication logic, by which each case is used to confirm or reject theoretical patterns emerging from others (Yin, 1994).

Dudalina is Brazil's largest exporter of shirts. In 2014, the firm was acquired by two large North American private equity groups, the Advent Group and Pincus, who account for the largest retail share of high-end fashion in Brazil. CINEX was founded in 1997 and is a Brazilian firm that produces aluminium and glass doors and has a share of the high-quality furniture market that exceeds $90 \%$. The company's headquarters are based in the town of Bento Gonçalves, but the firm also has a laboratory in Italy dedicated to product design and manufacture (Treviso). TDV is a Brazilian firm that is a point of reference in the Latin American dental products industry. In 2015, it was purchased by the French firm Septodont SA, world leader in the anaesthetics industry, operating in more than 150 countries with production subsidiaries in France, North America and India. ATOM is an Italian firm that is a global leader in cutting systems for flexible and semi-rigid materials. A complex process of diversification in products, geographic locations, and sectors/markets, led to the creation of an international group that has successfully navigated two heavy international crises in the 
sector. 7-Pixel is a leader in Italy in the online shopping and price comparison sector. The firm is the host and developer of the portals TrovaPrezzi.it and ShoppyDoo.it. These portals are the price comparison leaders in Italy, with more than 5 million monthly searches on data that are updated daily from over 2,000 merchants. Since 2005, the firm has been attempting to internationalise in different countries, achieving success in France and Spain, but failing in Poland and Brazil. Finally, Torrevilla is an Italian firm that has produced wine since 1907. The firm has only been incrementally expanding in foreign markets since the 1990s, when it started to attend international trade fairs in partnership with a more experienced Italian firm. Table 3 illustrates the firms' internationalisation paths and related entry modes. 
Table 2. Details of case firms

\begin{tabular}{|c|c|c|c|c|c|c|c|}
\hline Firm & Year of constitution & $\begin{array}{l}\text { Size (= number of } \\
\text { employees) }\end{array}$ & $\begin{array}{l}\text { Turnover in USD in } \\
2015\end{array}$ & $\begin{array}{c}\text { Foreign Sales/Total } \\
\text { Sales }\end{array}$ & Industry & Main products & $\begin{array}{c}\text { Year of } \\
\text { internationalisation to } \\
\text { Italy/Brazil }\end{array}$ \\
\hline $\begin{array}{c}\text { DUDALINA } \\
\text { Located in Sao } \\
\text { Paulo (Brazil) }\end{array}$ & 1953 & 1,100 & 108 million & $5 \%$ & $\begin{array}{l}\text { Textiles, wearing } \\
\text { apparel, leather }\end{array}$ & Shirts & 2012 \\
\hline $\begin{array}{c}\text { CINEX } \\
\text { Located in Bento } \\
\text { Gonçalves (Brazil) }\end{array}$ & 1998 & 351 & 5 million & $1 \%$ & $\begin{array}{l}\text { Home furniture and } \\
\text { accessories }\end{array}$ & $\begin{array}{l}\text { Windows, doors, } \\
\text { components for } \\
\text { furniture }\end{array}$ & 1993 \\
\hline $\begin{array}{c}\text { TDV } \\
\text { Located in } \\
\text { Pomerode (Brazil) }\end{array}$ & 1989 & 76 & 3.6 million & $30 \%$ & Dental & $\begin{array}{l}\text { Products for } \\
\text { dentistry }\end{array}$ & 2006 \\
\hline $\begin{array}{c}\text { АTом } \\
\text { Located in } \\
\text { Vigevano (Italy) }\end{array}$ & 1946 & 103 & 48 million & $80 \%$ & $\begin{array}{l}\text { Cutting of flexible } \\
\text { and semi-rigid } \\
\text { materials }\end{array}$ & $\begin{array}{l}\text { Machines for } \\
\text { cutting and } \\
\text { processing leather } \\
\text { and man-made } \\
\text { materials for } \\
\text { footwear and leather } \\
\text { goods industries: } \\
\text { Die cutting } \\
\text { machines, knife } \\
\text { cutting systems } \\
\text { continuous cutting } \\
\text { tables, machines for } \\
\text { preparation of } \\
\text { uppers, injection } \\
\text { moulding machines }\end{array}$ & Late $1980 \mathrm{~s}$ \\
\hline $\begin{array}{c}\text { 7-Pixel } \\
\text { Located in Giussago } \\
\text { (Italy) }\end{array}$ & 2002 & 126 & 15 million & $2.5 \%$ & $\begin{array}{l}\text { Internet comparing } \\
\text { prices engines }\end{array}$ & $\begin{array}{c}\text { Search engines } \\
\text { (Trovaprezzi, } \\
\text { ShoppyDoo, } \\
\text { MissHobby, } \\
\text { Drezzy) }\end{array}$ & 2007 \\
\hline $\begin{array}{c}\text { Torrevilla } \\
\text { Located in Torrazza } \\
\text { Coste (Italy) }\end{array}$ & 1907 & 15 & 7 million & $3 \%$ & Food and beverage & $\begin{array}{c}\text { Wines and } \\
\text { Sparkling Wines }\end{array}$ & 2011 \\
\hline
\end{tabular}


Table 3. Case firms' internationalisation processes

\begin{tabular}{|c|c|}
\hline Firm & Internationalisation process \\
\hline $\begin{array}{c}\text { Dudalina } \\
\text { (BRA) }\end{array}$ & $\begin{array}{l}\text { 1970s: Paraguay, Venezuela and Argentina (export) } \\
\text { 2000 - 2012: Latin America (export via Private Labels for fashion brands) } \\
\text { 2012: Italy (showroom) } \\
\text { 2012: Panama (showroom) } \\
\text { 2014: the firm was acquired by Restoque (Brazilian company) } \\
\text { 2015: Italy (mega store) } \\
\text { In 2016, the firm had } 16 \text { franchisees: Latin America (12), Stockholm (1), Kuala Lumpur } \\
\text { (1), Astana (Kazakhstan) (1), Milan (Italy) (1). }\end{array}$ \\
\hline $\begin{array}{l}\text { Cinex } \\
\text { (BRA) }\end{array}$ & $\begin{array}{l}\text { 1993: Italy (office) } \\
\text { 1998: Mercosur (Argentina, Brazil, Paraguay, Uruguay, Venezuela) (export) } \\
\text { 1999: Germany (partnership with Raumplus - German firm) } \\
\text { 2000: Italy (partnership with Rimadesio - Italian firm) } \\
\text { 2000-2003: USA (production subsidiary) } \\
\text { 2004 - Italy (strategic alliance with Studio Design DECOMA - Italian company) } \\
\text { 2005 - Mexico (Transfer of the US subsidiary to Mexico) } \\
\text { 2014 - US (Commercial representatives in Miami) } \\
\text { 2015 - US (Partnership with Corning - American company) }\end{array}$ \\
\hline $\begin{array}{l}\text { TDV } \\
\text { (BRA) }\end{array}$ & $\begin{array}{l}\text { 1990: Partnership with FedEx } \\
\text { 1994: Argentina (export) } \\
\text { 2003: Latin America (export) } \\
\text { 2005: Mexico (exclusive distributor) } \\
\text { 2005-2006: US (export) } \\
\text { 2006: Italy (export) } \\
\text { 2008: Iran, Saudi Arabia (export) } \\
\text { 2015: TDV was acquired by Septodont (French company) } \\
\text { The firm now exports to more than } 65 \text { countries all over the World. }\end{array}$ \\
\hline $\begin{array}{c}\text { ATOM } \\
\text { (ITA) }\end{array}$ & $\begin{array}{l}\text { 1960s: Greece, Turkey and Spain (export via a network of distributors) } \\
\text { 1975: US (export via a network of distributors) } \\
\text { 1993: Brazil (subsidiary) } \\
\text { 2003: China (2 subsidiaries) } \\
\text { 2011: US subsidiary }\end{array}$ \\
\hline $\begin{array}{c}\text { 7-Pixel } \\
\text { (ITA) }\end{array}$ & $\begin{array}{l}\text { 2005: Spain (local distributor) } \\
\text { 2006: Spain (commercial office) } \\
\text { 2008: Spain (subsidiary) } \\
\text { 2006: France, Poland (local distributor) } \\
\text { 2007: France, Poland (commercial office) } \\
\text { 2007: France, Poland (subsidiary) } \\
\text { 2007: Brazil (failed attempt to partner with local firms and establish itself in the market) } \\
\text { 2011: The firm was acquired by Naspers group (South African company) } \\
\text { 2011: De-internationalisation from Poland and Brazil }\end{array}$ \\
\hline $\begin{array}{c}\text { Torrevilla| } \\
\text { (ITA) }\end{array}$ & $\begin{array}{l}\text { 1996: Hong Kong (export via a local partner) } \\
\text { 2000: Germany, Switzerland, UK (unsolicited export) } \\
\text { 2008. China (subsidiary) } \\
\text { 2011: Brazil (partnership with more experienced Italian firm of the wine industry to } \\
\text { then export via personal contacts with two distributors) }\end{array}$ \\
\hline
\end{tabular}

\subsection{Data sources}

Our empirical work combines two main sources of data: in-depth interviews and archival data. Triangulation increases the reliability of the data presented and mitigates the retrospective/interpretation biases potentially arising from the interviewees (Jick, 1979).

Interviews. Overall, we were able to conduct 13 in-depth interviews with either the entrepreneur/founder/owner, or the manager in charge of the internationalisation process (see 
Table 4 for details). These are all knowledgeable informants who actively took part in the decision-making processes of multiple stages of the internationalisation processes and as such, are reliable sources of information on distance perceptions and strategic decisions. Before conducting the interviews, a detailed e-mail was sent to the firm to explain the objectives of the study, together with a summary of the research plan. Interviews - lasting between 60 and 100 minutes each - were designed to address our research objectives. To achieve them, and as suggested by Tung \& Verbeke (2010), we investigated several types of distance: cultural, institutional, economic and geographic. Interviews were used to retrospectively reconstruct the Internationalisation process and to track, in real time, the internationalisation moves and strategies. When conducting each of our structured interviews, we started by asking a set of questions regarding the firm's Internationalisation process. Specifically, we requested the following information: the year the company began international activities; the year the company approached Brazil/Italy for the first time; and the time and sequence of each mode of entry into the Brazilian/Italian market. We then proceeded by asking a set of open ended questions aimed at investigating distance perceptions (psychic distance) related to the Italian/Brazilian context (specifically, perceptions of geographic, cultural, economic, and institutional/administrative distance), and the decisions to enter these countries. The interviews were audiotaped and transcribed within 24 hours of the interview and the transcripts were then translated into English.

Archival data. We triangulated interview data with secondary data, as mentioned above. Overall, we were able to collect 20 press releases, 15 newspaper articles, company reports from ORBIS database, miscellaneous information from proprietary web sites and other reports. These data helped us to triangulate information regarding the internationalisation process, to elucidate any incongruence or ambiguities emerging from the interviews and/or to confirm particular statements. Triangulation with the abovementioned 
secondary data was also helpful to check whether the firms' strategic intentionality, as stated by our informants, translated into actual internationalisation outcomes, as formally presented in reports and official documents.

Nevertheless, the majority of issues related to our research aims emerged from the indepth interviews, since these were conducted with the primary objective of focusing on firmspecific internationalisation strategies, whilst also taking into account the managers' subjective perceptions and intentionality.

Table 4. Informants and number of interviews

\begin{tabular}{|c|c|c|}
\hline Firm & Informant & $\begin{array}{c}\text { Number of } \\
\text { interviews }\end{array}$ \\
\hline Dudalina (BRA) & Head of Internationalisation & 3 \\
\hline Cinex (BRA) & Owner (Founder) & 2 \\
\hline TDV (BRA) & Owner & 2 \\
\hline ATOM (ITA) & CEO & 2 \\
\hline 7-Pixel (ITA) & CEO (Founder) & 2 \\
\hline Torrevilla (ITA) & CEO & 2 \\
\hline
\end{tabular}

\subsection{Data analysis}

Consistent with the multiple case study approach (Eisenhardt, 1989) we first conducted a single case analysis for each firm and then proceeded with a cross-case comparison. First, we synthesized all the interview and archival data for each firm into several tabular displays, pooling quotes from in-depth interviews and archival data. Concurrently we produced single case histories, used as a basis for the single case analyses focused on the following dimensions: i) the internationalisation process as a whole, ii) distance perceptions of Brazilian (Italian) firms about Italy (Brazil), iii) firm-specific strategic objectives for entering Italy (Brazil).

In the second stage, we cross-compared the cases to identify similarities, differences, and potential recurring patterns regarding distance perceptions and the main strategic motives for internationalisation in relation to factors of foreign market attractiveness. In both stages, to identify instances of these constructs, we codified evidence stemming from interviews (the 
quotations) building on the notions of distance, strategic objectives, and foreign market attractiveness put forward in the theoretical framework.

The cross-comparison process led us to abstract from the empirical evidence and to advance a set of propositions and a model, considered the preliminary step for later testing with more ample data sets. Overall, this was achieved by (i) pooling interview transcripts and secondary data, and (ii) systematically combining empirical observations and existing theory, in order to expand our understanding of the theory and the empirical phenomena (Dubois \& Gadde, 2002).

\section{SINGLE CASE ANALYSES}

We will first illustrate our single case analyses, including the most representative quotations from the interviews.

Table 5 presents additional representative quotes used as the basis for the subsequent cross-case comparison to identify emerging patterns. We organized the quotations according to the key topics we were investigating. We hypothesised that firms seek alignment between a market attractiveness and their strategic objectives, as discussed in section 2 . We thus considered both factors, and compared them with the different dimensions of distance, as perceived by our respondents. We included the distance constructs that are most investigated in IB studies, i.e. cultural, geographic, institutional (including aspects of administrative differences), and economic (mostly in terms of internal demand characteristics) distance, as perceived by our respondents. Their perceptions of these distance dimensions (psychic distance) can be compared with the "objective" measures reported in a previous section. Each quote is preceded by the specific aspect of the respective construct (as presented in the title of each column of Table 5) illustrated by the quote. 
Table 5. Foreign market attractiveness, strategic objectives, and perceptions of distance: Quotes from informants

\begin{tabular}{|c|c|c|c|c|c|c|}
\hline Firm & $\begin{array}{c}\text { Foreign market } \\
\text { attractiveness factors }\end{array}$ & Strategic objectives & $\begin{array}{c}\text { Institutional/Administrative } \\
\text { distance }\end{array}$ & Cultural distance & Geographic distance & Economic distance \\
\hline $\begin{array}{l}\text { DUDALINA } \\
\text { (BRA) }\end{array}$ & $\begin{array}{l}\text { MARKET POTENTIAL } \\
\text { "We see great market } \\
\text { potential because in Italy } \\
\text { we can also sell to } \\
\text { tourists: it would be } \\
\text { impossible to rely just } \\
\text { on internal Italian clients } \\
\ldots \text { there won't be as } \\
\text { much demand as we } \\
\text { need. But, we can sell to } \\
\text { Russian tourists coming } \\
\text { to Milan." } \\
\text { CUSTOMER- } \\
\text { PRODUCT FIT } \\
\text { "The higher quality } \\
\text { demanded by Italian } \\
\text { customers can be a } \\
\text { stimulus for us to search } \\
\text { for better products and } \\
\text { deliver higher quality, } \\
\text { which is important for a } \\
\text { better positioning" }\end{array}$ & $\begin{array}{l}\text { BRAND } \\
\text { POSITIONING } \\
\text { "In Italy, we face } \\
\text { higher costs in terms of } \\
\text { marketing and } \\
\text { advertising to try } \\
\text { position the brand. } \\
\text { Nonetheless, we need } \\
\text { to position the brand, } \\
\text { and we are actually } \\
\text { managing to do so: our } \\
\text { brand needs to be } \\
\text { recognized in the } \\
\text { European area if we } \\
\text { want to gain } \\
\text { reputation. This will } \\
\text { give us access to a } \\
\text { bigger market" } \\
\text { LEGITIMIZATION } \\
\text { "Italy is a strategic } \\
\text { location, a hub for both } \\
\text { the whole EU market, } \\
\text { and later, for } \\
\text { approaching the US } \\
\text { market" }\end{array}$ & $\begin{array}{l}\text { REGULATORY REGIME } \\
\text { "Bureaucracy and standards } \\
\text { are extremely demanding and } \\
\text { complex in Italy" } \\
\text { "Italy has a very good } \\
\text { processes of quality standard } \\
\text { certification: Italians are } \\
\text { highly concerned with the } \\
\text { cost and the benefits of } \\
\text { product quality" }\end{array}$ & $\begin{array}{l}\text { PERCEIVED CULTURAL } \\
\text { SIMILARITIES } \\
\text { "We do not really perceive } \\
\text { cultural differences from } \\
\text { Brazil. Overall I would say } \\
\text { that we did not experience } \\
\text { cultural problems. Also, } \\
\text { possibly, we did not perceive } \\
\text { differences because we could } \\
\text { rely on our Italian partner, in } \\
\text { a sense that helped us a lot } \\
\text { with understanding Italy, its } \\
\text { culture, and the Italian } \\
\text { lifestyle. It was easier to } \\
\text { approach the Italian market } \\
\text { too, thanks to our partner's } \\
\text { experience" }\end{array}$ & $\begin{array}{l}\text { COST OF EXPORT } \\
\text { RELATED TO } \\
\text { TRANSPORT } \\
\text { COSTS, AND } \\
\text { TAXES } \\
\text { "If I had to give you a } \\
\text { figure for what it costs } \\
\text { us to export to Italy, I } \\
\text { can tell you that for } \\
\text { the EU in general, we } \\
\text { have to add a } \\
\text { percentage that } \\
\text { corresponds to taxes } \\
\text { plus transport costs to } \\
\text { our production costs. } \\
\text { It is also the same } \\
\text { percentage we have to } \\
\text { add to export to the } \\
\text { US; while to export to } \\
\text { Australia the } \\
\text { percentage is } 15 \% \text { " }\end{array}$ & $\begin{array}{l}\text { DIFFERENCES IN } \\
\text { CUSTOMER } \\
\text { PREFERENCES } \\
\text { "There are some critical } \\
\text { differences in terms of } \\
\text { local demand in our } \\
\text { perspective: Italians } \\
\text { look at fashion, } \\
\text { Brazilian at the product } \\
\text { itself. At the same time, } \\
\text { Italians want higher } \\
\text { quality with fashion. If } \\
\text { your brand is able to } \\
\text { meet this objective than } \\
\text { you can stay in this } \\
\text { market, achieve a } \\
\text { reputation, and then also } \\
\text { aim for approaching } \\
\text { other European } \\
\text { countries where you } \\
\text { need to have a strong } \\
\text { brand positioning." } \\
\text { "This type of demand } \\
\text { from customers } \\
\text { challenges your firm } \\
\text { and your products. We } \\
\text { needed to meet those } \\
\text { quality expectations ... } \\
\text { the ones demanded by } \\
\text { Italians... and we } \\
\text { strived to do so. I think } \\
\text { this was the challenge } \\
\text { we accepted while we } \\
\text { were looking at Italy as } \\
\text { a potential market" }\end{array}$ \\
\hline
\end{tabular}


Table 5. continued

\begin{tabular}{|c|c|c|c|c|c|c|}
\hline $\begin{array}{l}\text { CINEX } \\
\text { (BRA) }\end{array}$ & $\begin{array}{l}\text { MARKET POTENTIAL } \\
\text { "Italy is an innovative } \\
\text { country. } \\
\text { There is a well- } \\
\text { developed market for } \\
\text { creativity and design. } \\
\text { We could learn a lot } \\
\text { from the local } \\
\text { technologies and quality } \\
\text { standards, and we can } \\
\text { still improve" } \\
\text { "Brazilian firms in } \\
\text { general, and ourselves, I } \\
\text { would say ... are now } \\
\text { beginning to aim for } \\
\text { those high-quality levels } \\
\text { that Italian clients ask } \\
\text { for" } \\
\text { CUSTOMER- } \\
\text { PRODUCT FIT } \\
\text { "Italians are very } \\
\text { demanding in terms of } \\
\text { quality and technology: I } \\
\text { believe that customers } \\
\text { demanding high quality } \\
\text { products foster us to } \\
\text { improve our quality } \\
\text { standards and achieve a } \\
\text { better positioning in } \\
\text { Italy, but also in Europe } \\
\text {... as well as higher } \\
\text { returns of course" }\end{array}$ & $\begin{array}{l}\text { BRAND } \\
\text { POSITIONING } \\
\text { "Italy is important for } \\
\text { us if we want to } \\
\text { position our brand as a } \\
\text { higher quality one. We } \\
\text { think our customers } \\
\text { will be satisfied in } \\
\text { terms of quality with } \\
\text { the products that we } \\
\text { have entirely } \\
\text { developed in Italy" } \\
\text { LEGITIMIZATION } \\
\text { "A better positioning in } \\
\text { Italy will help us to } \\
\text { have a better one also } \\
\text { in other European } \\
\text { countries" } \\
\text { UPGRADE } \\
\text { "We have decided to } \\
\text { establish an Italian } \\
\text { office that develops } \\
\text { new products because } \\
\text { we want to learn about } \\
\text { technological } \\
\text { advancements and best } \\
\text { practices" }\end{array}$ & $\begin{array}{l}\text { LEGAL FRAMEWORK } \\
\text { AND ITS ENFORCEMENT } \\
\text { "Labour legislation is too } \\
\text { complex. Unions hold too } \\
\text { much power" }\end{array}$ & $\begin{array}{l}\text { PERCEIVED } \\
\text { DIFFERENCES IN DOING } \\
\text { BUSINESS } \\
\text { "Overall business practices } \\
\text { and the way doing business in } \\
\text { Italy are quite different from } \\
\text { those in Brazil" }\end{array}$ & $\begin{array}{l}\text { COST OF EXPORT } \\
\text { RELATED TO } \\
\text { PRODUCT } \\
\text { SPECIFICITIES } \\
\text { "We are unable to } \\
\text { export to Italy because } \\
\text { we have a product that } \\
\text { is too heavy and takes } \\
\text { up too much space. } \\
\text { For this reason, our } \\
\text { interest is to continue } \\
\text { to develop new } \\
\text { products directly in } \\
\text { Italy and then export } \\
\text { them to other } \\
\text { neighbouring } \\
\text { countries" }\end{array}$ & $\begin{array}{l}\text { DIFFERENCES IN } \\
\text { CUSTOMER } \\
\text { PREFERENCES } \\
\text { "There are differences } \\
\text { in terms of product } \\
\text { quality expectations: } \\
\text { Italians are more } \\
\text { demanding. I think that } \\
\text { their expectations of } \\
\text { quality have been a sort } \\
\text { of opportunity for us, } \\
\text { we needed to do better } \\
\text { and to meet that higher } \\
\text { standards. To meet this } \\
\text { demand's expectations } \\
\text { of higher quality } \\
\text { standards has been in a } \\
\text { sense the most engaging } \\
\text { part of our venture in } \\
\text { Italy. Now that I think } \\
\text { more about this...I can } \\
\text { affirm that we liked it. } \\
\text { We were attracted by } \\
\text { this challenge basically. } \\
\text { This was a quite strong } \\
\text { factor determining us } \\
\text { going to Italy" }\end{array}$ \\
\hline $\begin{array}{l}\text { TDV } \\
\text { (BRA) }\end{array}$ & $\begin{array}{l}\text { MARKET POTENTIAL } \\
\text { "Technical levels in } \\
\text { Italy are very high, both } \\
\text { of producers and those } \\
\text { expected by customers } \\
\text { in Italy, therefore there's } \\
\text { a great opportunity to } \\
\end{array}$ & $\begin{array}{l}\text { BRAND } \\
\text { POSITIONING } \\
\text { "Italy for us is } \\
\text { strategic... Italy means } \\
\text { quality. If you are able } \\
\text { to enter and remain in } \\
\text { the Italian market, the }\end{array}$ & $\begin{array}{l}\text { REGULATORY REGIME } \\
\text { "Import taxes in Brazil are } \\
\text { around } 60 \%, \text { while in Italy } \\
\text { only between } 2 \% \text { and } 8 \% " \\
\text { "Italy has quality standards } \\
\text { certifications that you need to } \\
\text { comoly with" }\end{array}$ & $\begin{array}{l}\text { PERCEIVED } \\
\text { DIFFERENCES IN DOING } \\
\text { BUSINESS } \\
\text { "I would say that we } \\
\text { encountered some problems } \\
\text { when interfacing with other } \\
\text { business people. Not that they }\end{array}$ & $\begin{array}{l}\text { TRANSPORT COST } \\
\text { RELATED TO } \\
\text { VOLUMES } \\
\text { EXPORTED } \\
\text { "The maximum } \\
\text { weight that we send to } \\
\text { Italv at a time is } 30 \mathrm{~kg} \text {. }\end{array}$ & $\begin{array}{l}\text { DIFFERENCES IN } \\
\text { CUSTOMER } \\
\text { PREFERENCES } \\
\text { "Italians are very } \\
\text { concerned with } \\
\text { weighting the costs and } \\
\text { benefit of quality. } \\
\end{array}$ \\
\hline
\end{tabular}


Table 5. continued

\begin{tabular}{|c|c|c|c|c|c|c|}
\hline & $\begin{array}{l}\text { learn and to improve our } \\
\text { quality standards. } \\
\text { CUSTOMER- } \\
\text { PRODUCT FIT } \\
\text { "I would say that higher } \\
\text { quality requirements by } \\
\text { customers can be an } \\
\text { opportunity for us to } \\
\text { meet higher levels and } \\
\text { improve our products" }\end{array}$ & $\begin{array}{l}\text { others will think you } \\
\text { have a good } \\
\text { reputation/status in } \\
\text { terms of quality. } \\
\text { "Italy is strategic to our } \\
\text { positioning, if we want } \\
\text { to enter other European } \\
\text { markets. Italians } \\
\text { generally do not trust } \\
\text { Brazilian products that } \\
\text { much. We hope that if } \\
\text { we meet higher quality } \\
\text { standards it will make it } \\
\text { easier to gain trust and } \\
\text { to grow market share" } \\
\\
\text { LEGITIMIZATION } \\
\text { "If you are able to } \\
\text { position as a quality } \\
\text { brand in Italy, then you } \\
\text { can be recognized as a } \\
\text { quality brand and get } \\
\text { chances to export to } \\
\text { other European } \\
\text { countries, where quality } \\
\text { is highly recognized. }\end{array}$ & & $\begin{array}{l}\text { were impolite or } \\
\text { unprofessional. Not at all! But } \\
\text { we have just different a timing } \\
\text { of do business and, possibly } \\
\text { also some different attitudes } \\
\text { when negotiating" }\end{array}$ & $\begin{array}{l}\text { because our clients do } \\
\text { not need to keep } \\
\text { stocks. We also have } \\
\text { an Italian partner that } \\
\text { helps us a lot with the } \\
\text { distribution" }\end{array}$ & $\begin{array}{l}\text { Italians are very } \\
\text { demanding in terms of } \\
\text { quality; the price is } \\
\text { secondary. While } \\
\text { Brazilians look more at } \\
\text { the price. At the same } \\
\text { time, the Italian } \\
\text { customer is loyal. Today } \\
\text { we export to the same } \\
\text { customers we started } \\
\text { exporting to since the } \\
\text { very beginning!" } \\
\text { "Italian customers' } \\
\text { requirements for higher } \\
\text { quality have been a real } \\
\text { stimulus for the firm to } \\
\text { go to that market and } \\
\text { meet this challenge" } \\
\\
\text { DIFFERENCES IN } \\
\text { PURCHASING POWER } \\
\text { "Italian customers are } \\
\text { willing to pay higher } \\
\text { prices for quality } \\
\text { products than Brazilian } \\
\text { customers" }\end{array}$ \\
\hline $\begin{array}{l}\text { ATOM } \\
\text { (ITA) }\end{array}$ & $\begin{array}{l}\text { MARKET GROWTH } \\
\text { "We have always seen a } \\
\text { great market potential in } \\
\text { Brazil with regards to its } \\
\text { footwear market growth. } \\
\text { This was of course an } \\
\text { opportunity for our } \\
\text { cutting machines, that are } \\
\text { among the most excellent } \\
\text { in the World" }\end{array}$ & $\begin{array}{l}\text { SELL MORE } \\
\text { "Brazil has a niche } \\
\text { market for our firm's } \\
\text { products and used to } \\
\text { have very little } \\
\text { competition when we } \\
\text { decided to approach it. } \\
\text { In particular, we saw an } \\
\text { opportunity offered by } \\
\text { the growth of the } \\
\text { footwear industry in } \\
\text { Latin America" } \\
\text { LEGITIMIZATION } \\
\text { "Brazil was conceived } \\
\text { as a bridge market for } \\
\text { other highlv important }\end{array}$ & $\begin{array}{l}\text { REGULATORY REGIME } \\
\text { "The level of protectionism is } \\
\text { very high compared to Italy" } \\
\text { "Import duties on footwear } \\
\text { machinery have historically } \\
\text { been high (more than } 30 \% \text { ) } \\
\text { making competition based on } \\
\text { price impossible and forcing } \\
\text { companies like ATOM to bet } \\
\text { on strong technological } \\
\text { differentiation, as well as } \\
\text { looking for a different model } \\
\text { of presence on the market." }\end{array}$ & $\begin{array}{l}\text { PERCEIVED DIFFERENCES } \\
\text { IN DOING BUSINESS } \\
\text { "We did find some cultural } \\
\text { differences in practicing } \\
\text { business in Brazil...yet at the } \\
\text { same time I would not say that } \\
\text { these could cause us troubles" }\end{array}$ & $\begin{array}{l}\text { TRANSPORT COST } \\
\text { RELATED TO } \\
\text { WEIGHT/VOLUME } \\
\text { RATIO } \\
\text { "In terms of costs, I } \\
\text { know that the } \\
\text { Weight } / \text { Volume ratio } \\
\text { of our cutting tables is } \\
\text { equal to } 240 \mathrm{~kg} / \mathrm{m} 3 \text { " }\end{array}$ & $\begin{array}{l}\text { SIMILARITIES IN } \\
\text { CUSTOMER } \\
\text { PREFERENCES } \\
\text { "We are a B2B firm, } \\
\text { therefore differences in } \\
\text { terms of customers' } \\
\text { preferences and so on, } \\
\text { are not relevant. What } \\
\text { matters for our B2B } \\
\text { buyers is the quality of } \\
\text { our machinery and the } \\
\text { reputation we have in } \\
\text { terms of the machinery's } \\
\text { performance, as in our } \\
\text { domestic market" }\end{array}$ \\
\hline
\end{tabular}


Table 5. continued

\begin{tabular}{|c|c|c|c|c|c|c|}
\hline & & $\begin{array}{l}\text { markets for us in } \\
\text { Central and Southern } \\
\text { America }\end{array}$ & & & & \\
\hline $\begin{array}{l}\text { 7-PIXEL } \\
\text { (ITA) }\end{array}$ & $\begin{array}{l}\text { MARKET POTENTIAL } \\
\text { "Generally, I would say } \\
\text { that I saw some market } \\
\text { potential in Brazil to } \\
\text { develop innovative } \\
\text { search engines leveraging } \\
\text { the local expertise } \\
\text { there...Usually I am } \\
\text { interested in those } \\
\text { markets where I see } \\
\text { potential to innovate and } \\
\text { learn more. } \\
\text { "In Brazil, we thought } \\
\text { there were opportunities } \\
\text { in terms of both } \\
\text { customers and } \\
\text { merchants" }\end{array}$ & $\begin{array}{l}\text { SELL MORE } \\
\text { "We had the belief that } \\
\text { we had to be present } \\
\text { because this market was } \\
\text { a high growth one and it } \\
\text { was expected to be very } \\
\text { dynamic in the future" } \\
\text { UPGRADE } \\
\text { "I usually prefer to go } \\
\text { and see directly in the } \\
\text { market to try exploit } \\
\text { some of the } \\
\text { opportunities it gives. } \\
\text { When I go in a foreign } \\
\text { country, as in the case } \\
\text { of Brazil, I like to } \\
\text { experiment with local } \\
\text { technologies to develop } \\
\text { new search engines. We } \\
\text { do not really make } \\
\text { extensive market } \\
\text { analyses, rather we go } \\
\text { to the market and try to } \\
\text { carve out business. } \\
\text { Brazil in our } \\
\text { perspective had many } \\
\text { opportunities that we } \\
\text { could exploit, but we } \\
\text { also underestimated } \\
\text { many cultural and } \\
\text { institutional factors" } \\
\text { LEGITIMIZATION } \\
\text { "...By the way, more } \\
\text { importantly, I thought } \\
\text { we could succeed in } \\
\text { Brazil because of the } \\
\text { previous experiences } \\
\text { we had in Spain" }\end{array}$ & $\begin{array}{l}\text { LEGAL FRAMEWORK } \\
\text { AND ITS ENFORCEMENT } \\
\text { "At the very beginning I } \\
\text { thought Brazil was quite } \\
\text { close to us in terms of } \\
\text { institutions...then I realized } \\
\text { that it was not so. } \\
\text { REGULATORY REGIME } \\
\text { "Regulations and many } \\
\text { administrative aspects are } \\
\text { different, complicated, and } \\
\text { require a direct and close } \\
\text { approach in the market to } \\
\text { monitor and manage them" }\end{array}$ & $\begin{array}{l}\text { PERCEIVED DIFFERENCES } \\
\text { IN DOING BUSINESS } \\
\text { "Cultural factors have been } \\
\text { much more influential and } \\
\text { critical than what we expected } \\
\text { in the first instance. } \\
\text { Particularly, because of highly } \\
\text { different attitudes in doing } \\
\text { business, I think that we have } \\
\text { not been able to properly } \\
\text { establish a close and trustable } \\
\text { relationship with local } \\
\text { contacts that we could rely on } \\
\text { to approach the complexities } \\
\text { of the market, that we were } \\
\text { beginning to experience and } \\
\text { that we had underestimated." }\end{array}$ & $\begin{array}{l}\text { COST OF EXPORT } \\
\text { RELATED TO } \\
\text { PRODUCT } \\
\text { SPECIFICITIES } \\
\text { "To us Brazil was not } \\
\text { distant in terms of } \\
\text { mere kilometric } \\
\text { distance, and I think } \\
\text { this is because of the } \\
\text { nature of our business. } \\
\text { Our products are online } \\
\text { engines for comparing } \\
\text { products' prices and do } \\
\text { not need to be } \\
\text { physically exported. } \\
\text { Having experienced } \\
\text { difficulties in finding a } \\
\text { local trusted contact, } \\
\text { we managed the } \\
\text { market remotely from } \\
\text { Italy." }\end{array}$ & $\begin{array}{l}\text { DIFFERENCES IN } \\
\text { CUSTOMER } \\
\text { PREFERENCES } \\
\text { "I would say that I could } \\
\text { notice the kind of } \\
\text { customers we } \\
\text { approached in Brazil to } \\
\text { have a different attitude } \\
\text { than those we have in } \\
\text { Italy or also in Spain... } \\
\text { put, as I told you } \\
\text { before...I strongly } \\
\text { believe that it is from } \\
\text { different contexts and } \\
\text { people that we can creatc } \\
\text { opportunities" }\end{array}$ \\
\hline
\end{tabular}


Table 5. continued

\begin{tabular}{|c|c|c|c|c|c|c|}
\hline $\begin{array}{l}\text { TORREVILLA } \\
\text { (ITA) }\end{array}$ & $\begin{array}{l}\text { MARKET POTENTIAL } \\
\text { "There is a market in } \\
\text { Brazil either for medium- } \\
\text { high quality wines, or for } \\
\text { medium-low quality } \\
\text { ones." } \\
\text { CUSTOMER- } \\
\text { PRODUCT FIT } \\
\text { "Generally, Brazilians } \\
\text { prefer sweet wine, so we } \\
\text { thought we could meet } \\
\text { this demand with some of } \\
\text { our current wine } \\
\text { production" }\end{array}$ & $\begin{array}{l}\text { SELL MORE } \\
\text { "We analysed the } \\
\text { market and understood } \\
\text { that there was a demand } \\
\text { for sweet wines. Brazil } \\
\text { is also a strategic } \\
\text { location because it will } \\
\text { have a huge demand for } \\
\text { wines soon so we } \\
\text { decided that, also } \\
\text { thanks to a partnership } \\
\text { with an already } \\
\text { experienced firm, we } \\
\text { could try to tackle this } \\
\text { growing demand" } \\
\text { "We had the chance to } \\
\text { partner with another } \\
\text { Italian firm that already } \\
\text { had experience in the } \\
\text { market, so we thought } \\
\text { that through this firm } \\
\text { we would actually have } \\
\text { more chances to enter } \\
\text { the market thanks to its } \\
\text { knowledge and help } \\
\text { with a myriad of } \\
\text { practical problems, } \\
\text { especially bureaucracy, } \\
\text { directly in the market" }\end{array}$ & $\begin{array}{l}\text { REGULATORY REGIME } \\
\text { "Brazil has bureaucratic } \\
\text { labelling costs, and tariffs" } \\
\text { "Protectionist policies: tariffs } \\
\text { on imported wine (more than } \\
150 \% \text { of the cost price). Such } \\
\text { duties also differ among the } \\
\text { Brazilian states. } \\
\text { "Artificial barriers are very } \\
\text { strict and have highly specific } \\
\text { rules" } \\
\text { LEGAL FRAMEWORK } \\
\text { AND ITS ENFORCEMENT } \\
\text { "Unfavourable exchange rate, } \\
\text { unfavourable government } \\
\text { rules for alcoholic } \\
\text { consumption. Wine prices in } \\
\text { Brazil are extremely high" }\end{array}$ & $\begin{array}{l}\text { PERCEIVED DIFFERENCES } \\
\text { IN CONSUMPTION } \\
\text { CULTURAL TRAITS } \\
\text { "I tried to rely on the } \\
\text { experience of the other firms } \\
\text { we partnered. He [the } \\
\text { entrepreneur] was much more } \\
\text { experienced than me and } \\
\text { knew the Brazilian culture. } \\
\text { From his experience and my } \\
\text { understanding, I think they are } \\
\text { not far from our culture. } \\
\text { Nonetheless, one thing that I } \\
\text { could understand is that } \\
\text { Brazilians do not really have a } \\
\text { wine culture, so this can either } \\
\text { be an opportunity, but also a } \\
\text { threat. We need to be careful } \\
\text { with promoting our wines, and } \\
\text { sometimes educate the } \\
\text { customer" }\end{array}$ & $\begin{array}{l}\text { TRANSPORT COST } \\
\text { RELATED TO } \\
\text { PRODUCT } \\
\text { SPECIFICITIES } \\
\text { "To us I would say that } \\
\text { the problem is not } \\
\text { really in terms of } \\
\text { number of } \\
\text { kilometres... What } \\
\text { matters to us when we } \\
\text { export our product - } \\
\text { regardless of location - } \\
\text { is cargo companies' } \\
\text { efficiency in } \\
\text { maintaining product } \\
\text { integrity (wine bottles) } \\
\text { and the speed of } \\
\text { reaching Brazilian } \\
\text { harbours. Integrity is } \\
\text { important...if cargos } \\
\text { are not reliable, it } \\
\text { means losses for us..." }\end{array}$ & $\begin{array}{l}\text { DIFFERENCES IN } \\
\text { PURCHASING POWER } \\
\text { "Local demand for wines } \\
\text { is quite varied. There is a } \\
\text { growing number of } \\
\text { customers able to buy } \\
\text { not only our lower } \\
\text { quality wines, but also } \\
\text { our medium-high ones, } \\
\text { especially the sweet } \\
\text { ones. This variety in } \\
\text { consumer demand makes } \\
\text { Brazil very attractive for } \\
\text { our products" }\end{array}$ \\
\hline
\end{tabular}




\subsection{Dudalina (BRA)}

Internationalisation process. The firm began its internationalisation in the 1970s, exporting to Paraguay, Venezuela, and Argentina. By 2003, the firm was exporting $22 \%$ of its production, mostly to Mercosur countries, through Private Labels of local fashion brands. In 2012, it opened its first showroom in Milan, and a franchise in Panama; then in 2015, Dudalina open a proprietary megastore in Milan. By 2016, the firm owned a total of 16 franchised shops around the world.

Distance perceptions. As mentioned by our respondent, in the perspective of this firm, Italy is relatively distant in terms of administrative differences, "Italy is quite complex with regards to high bureaucracy, and taxation. The issues are quite different from those we experience in Brazil". Then there are differences in terms of local demand characteristics (economic distance): "Italians are more concerned with fashion trends. Italians expect a product that is both fashionable and a high quality one, while Brazilians are generally more concerned with product features, in terms of performance". At the same time, according to the firm's Head of Internationalisation (HoI), the expectations of local demand were seen by the firm as an attractive opportunity to position itself as a higher quality brand: "Italians push for higher quality, we wanted to get involved in the market and take this challenge ...we knew that if we were able to meet such standards it would have meant that we could satisfy Italian customers, and possibly other European ones". The firm's strategic objective of brand positioning counterbalanced the perception of economic differences in terms of customer preferences, turning them into factors for enabling internationalisation.

Strategic objectives. Dudalina entered the Italian market with the intention of using it first as hub for the rest of the European (and Russian) markets, and then as hub to enable the entry in the US market, based on the increased brand reputation it hoped to gain in Europe. According to the HoI, "Italy is strategic because it gives us the chance - if we can, of course - 
to position ourselves in the European market thanks to increased brand reputation and awareness. I believe that a good brand positioning in Europe will also be critical for positioning in the US, because American customers like European fashion brands a lot". Specifically, the firm chose to locate in Milan - and no other place in Italy - because the city was considered the only strategic location for gaining a reputation in the European market, and subsequently approach the US market. According to Dudalina's HoI: "it does not matter that the firm is not making any profit from this activity (i.e. from its flagship store in Milan). Milan is geographically strategic because it is a hub for Europe and Russia, and strategic from the point of view of brand reputation - needed to enter the US market".

\subsection{CINEX (BRA)}

Internationalisation process. In 1993, the owner, Cesar Cini, decided to set up an office in Treviso, Italy, the location of one of the largest furniture manufacturing centres in Europe. Right from the outset, the entrepreneur worked to develop links between Brazil and Italy to exchange technology and define trends. With the help of business contacts in Italy, and using its international experience and knowledge, the firm set up its first office in Brazil. In 1997, the firm began to build a manufacturing plant in Brazil. This proved to be a difficult process and it had to invest heavily in marketing to introduce a new product in Brazil. Nonetheless, in 1999, production volumes increased and CINEX entered its first partnership with Raumplus, a German firm, to manufacture in Brazil under license. The following year, CINEX entered a partnership with the Italian firm Rimadesio, a well-known global brand that makes aluminium and glass doors. An intensive process of knowledge transfer and product development was initiated. In 2002, a greenfield production facility was established in Kernersville, North Carolina, in the United States. The creation of the subsidiary was driven by CINEX's American supplier and the firm started supplying two giants of the North- 
American furniture industry: Steelcase and Hermann Miller. The partnership with Italy was further strengthened by an alliance formed in 2004 with design studio Decoma. CINEX also entered another niche market (tables and chairs) as licensee of the Swiss brand CHform. In 2003, having gained experience, CINEX began to export to Bolivia, Peru, Chile, Uruguay, the United States, and Angola. In 2005, CINEX transferred its American subsidiary to Mexico. In 2008, the CINEX Lab (the company's centre for intelligence, innovation and design) was established in the city of Treviso, which is located in Veneto (in the north-east of Italy), and is part of one of the most important furniture clusters in Italy - and in Europe - where knowledge is embedded and shared within the network.

Distance perceptions. Our respondent from CINEX perceives great institutional/administrative distance and relatively high cultural and economic distances. In the words of CINEX's CEO: "In Italy, labour legislation is too complex". Regarding cultural distance, apart from reporting differences related to business practices, he states that "The south of Brazil is similar to northern Italy in terms of religious and culinary habits; at the same time Italians are extremely suspicious, thus it is very difficult to convince Italians in our industry of the quality of a foreign product, especially if it comes from Brazil". With respect to economic distance he stresses: "Italians are highly concerned with the cost and the benefits of product quality. But we knew it. We thought that we should have try go in the market, do our best, and meet these expectations. This was the exciting part of the story". As in the case of Dudalina, the firm perceived economic distance as an opportunity.

Strategic objectives. For CINEX, Italy is a hub for exporting to other European countries, that otherwise would not be reachable directly from Brazil. Locating in Italy is strategic because consumer demand for higher quality has encouraged the firm to raise its quality standards. Italy is, at the same time, the place to gain technological know-how in order to raise quality: "It is strategic because we can gain the technological know-how necessary to 
develop the higher quality products required, in order to attempt to access the highly competitive European furniture industry" (CEO). This was possible thanks to the firm's partnerships and strategic alliances with Italy, its establishment of a dedicated office, and a R\&D Lab in Treviso to develop new products with the objective of acquiring knowledge and learning as much as possible. With a similar aim, but in a different location, CINEX also decided to establish a partnership with an American firm to develop an innovative type of glass for smart phones: "We try to adapt products for local markets: with an American partner, we are developing a super-thin glass for the Apple iPhone. If we manage to develop it, we will export a lot more, to more distant markets" (CEO). For CINEX, high institutional/administrative distance could be overcome because Italy was regarded a strategic location in which to gain know-how and achieve its strategic objectives to position the brand and upgrade.

\subsection{TDV (BRA)}

Internationalisation process. The firm's internationalisation process started in 1994. From that point up to 2003, it only exported in small quantities, mainly to Argentina. In 2003, with a new foreign executive, TDV began exporting to other Latin American countries. TDV started to export to Italy in 2006; the Italian market now represents $15 \%$ of its total foreign sales. In 2015, TDV was acquired by Septodont, a French company. Septodont exports to more than 150 countries and, according to our respondent "TDV will hopefully be able to take advantage of this global market". The two companies' products are complementary. Today, TDV's products are found on the shelves of more than 65 countries.

Distance perceptions. As for CINEX, our TDV's respondent reported relatively high cultural differences in terms of the way business is conducted in Italy. Economic distance in terms of consumers' preferences is critical for TDV. According to our respondent, Italian 
customers have very high quality expectations: "it is very difficult to convince Italian customers of the quality of a foreign product, especially if it is Brazilian". And these high expectations have created an opportunity, pushing the firm to manufacture higher quality products: "We were looking at Italy to find the best practices in our industry, and of course we knew that customers were expecting high quality. But this was part of the game, the opportunity we seized to enhance the quality of our products". The same informant points out that their company's reputation with Italian customers may have improved thanks to the recent acquisition by the French firm. With regard to institutional differences, the representative of TDV is quite concerned about some regulatory aspects of certifications, yet he at the same time, considers Italian institutions to be more efficient than Brazilian ones "The institutions authorizing the entry of our products are fast and efficient. In Brazil, on the other hand, it can take up to a year to have a certificate issued. Italy is very fast".

Strategic objectives. The TDV informant confirms that the aim of accessing the rest of Europe was what led the firm to locate in Italy, because it was seen as a hub for gaining brand reputation. As the general manager puts it "If you are able to enter and remain in the Italian market, the other [markets] will think you have a good reputation/status in terms of quality". The high perceived economic distance was offset by the strategic objective of positioning the brand and upgrade. As for the previous two Brazilian cases, differences in economic demand appear to have provided motivation for the selection of the foreign market, rather than inhibiting it.

\section{$5.4 \operatorname{ATOM}($ ITA)}

Internationalisation process. ATOM has been intensively internationalised almost from its inception. From the early 1960s up until the mid-1980s, the firm established its own regional distribution networks in Greece, Turkey, Spain, and the US. As early as 1966, the firm's export intensity already represented $30 \%$ of its total sales. ATOM experimented its first 
direct export model in 1993, when it set up a subsidiary in Brazil. When its clients (footwear producers) underwent delocalization, ATOM followed them, establishing two subsidiaries in China, one in the Free Trade Zone of Shanghai, in 2000, and another in the Feng Xian district, in 2003. In 2011, the knowledge accumulated with local distributors in the US enabled the firm to establish a fully-owned subsidiary.

Distance perceptions. According to our respondent, the perceived institutional distance is great: "Institutional distance is huge because of the heavy protectionist policies, especially a complex system of tariffs and duties that penalizes foreign entrants" (CEO). At the same time, the cultural distance perceived is relatively low. Economic distance in terms of differences in demand was not referred as particularly relevant being the firm involved in B2B transactions.

Strategic objectives. The firm started to approach the Brazilian market during the end of the 1980s as a strategic choice to enter a flourishing footwear industry that shared common traits with the Italian one, such as concentration in clusters. The firm started exporting as a subcontractor for large international groups, in the absence of strong brands of Brazilian origin that could compete on the international market. The model was based on good relations with local non-exclusive dealers, who imported their standard product and then supplied it to the customer on demand. As the CEO told us "Our brand reputation at that time was enough. The protectionist policies of the Brazilian government had a strong impact on market dynamics". Faced with these challenges, and because of structural regulations, the traditional distribution model used up until then by ATOM in the rest of the world turned out to be quite inadequate. Additionally, during the 1990s the demand for specialized technologies was changing, becoming increasingly sophisticated and quality-oriented. After careful consideration, the decision was taken to partner with the Klein group, a local manufacturer of machinery for the footwear industry that had offered to make available to ATOM a dedicated 
operational structure, in addition to its distribution network. However, this collaboration did not work out, and so the firm decided to establish its own subsidiary, ATOM Distribudora. This Brazilian subsidiary acted as a strategic hub to serve customers in Brazil, and in Central and Southern America.

\subsection{7-Pixel (ITA)}

Internationalisation process. 7-Pixel began its internationalisation in 2005 when the firm entered Spain, first, through a local distributor and, later, through the establishment of a commercial office and the incorporation of a local firm. In 2006, the firm entered France and Poland through the same chain of events. During the same year, it also entered the Brazilian market, relying on a local contact person and attempting to establish itself there. Personal contacts were critical to the firm's entry to these markets. According to the CEO: "the greater the geographic distance, the more you need to trust the local contact". Between 2009 and 2011 the firm progressively ceased its activities in both Brazil and Poland. As described by our informant, the Brazilian failure was due to the fact that - unlike the French and Spanish experiences - the firm was ultimately unable to develop a trustworthy relationship with local representatives: "It was very difficult to find a reliable and constant person in Brazil; we could not really find anybody trustworthy in the end... so basically we ended up monitoring the market remotely from our Italian offices" (CEO). Concurrently, by 2011 , the Naspers group - which had acquired 7-Pixel in that year - became leader in the price-comparison engines sector in both markets, forcing 7-Pixel to abandon its projects there.

Distance perceptions. According to the CEO, the Brazilian experience was problematic because both institutional and cultural distances were large, and were underestimated in the first instance. In the words of our respondent: "there is a huge institutional distance in terms of artificial barriers. Moreover, we had underestimated the cultural distance 
and historical difference before entering the market. I had thought cultural and historical differences to be less influential then they actually proved to be" (CEO). As mentioned, 7Pixel was not able to settle through a trustworthy local dealer - and possibly, afterwards, with a local office - as they did in France and Spain, to reduce the distance and properly manage its customers with ad-hoc responses. As in the words of our informant, "success [in France and Spain] was achievable mainly because of the presence of a previous highly reliable personal contact acting as a bridge in overcoming local institutional and cultural problems, which we perceived as sources of uncertainty" (CEO). To manage the Brazilian market, the firm relied on a person working remotely from its Italian offices, thus failing to gain firsthand market knowledge, and gradually losing its ability to handle many bureaucratic issues and, consequently, to respond promptly to the demands of its customers. Although the CEO reported extents of economic distance, at the same time Brazil represented high growth potentials in terms of customers, as well as an opportunity for product development with local expertise.

Strategic objectives. According to the CEO, the strategic intention of internationalising to Brazil was to explore the market to exploit the market potential: a "highly dynamic and growing market that could be exploited in terms of both customers and merchants" (CEO). The CEO was quite convinced that Brazil represented a successful target market, thanks to the firm's successful experience in Spain. He believed the firm needed to have a close personal contact to directly manage the market. However, they were not able to find such a contact, and as a result, gradually lost the spillover gains provided by the relational learning processes, especially in highly complex institutional environments. The Brazilian failure was, at the same time, seen by the CEO as major source of feedback and in turn, of organizational learning "we need to have feedback, including negative feedback, if we want to learn. Attempts that went wrong are needed if we want to learn in order to do better" (CEO). 


\subsection{Torrevilla (ITA)}

Internationalisation process. One of this firm's first internationalisation activities dates back to 1996, when the firm began to enter Hong Kong with a local partner to distribute its wines. Afterwards, in 2000, the firm entered Spain, Great Britain and Germany, in partnership with another Italian firm, participating at international trade fairs and responding to unsolicited orders from local clients. In 2009, the firm opened a subsidiary in China. In 2011, Torrevilla entered the Brazilian market through a partnership with another Italian firm that already had experience in the Brazilian market. Additional relationship building through personal contacts with two distributors, in Belo Horizonte and São Paulo, further increased its exports during 2012.

Distance perceptions. According to the CEO, institutional/administrative distance is highly relevant, while cultural distance has an impact with respect to consumption wine habits which are very different from those in Italy. "We need stable and skilled [in our business] human resources but in Brazil, it is difficult to find the human resources we need. Regulation and bureaucracy are complex and heavy, mainly due to protectionist policies. On the other hand, Brazil is very similar in terms of culture...but they do not have a wine culture" (CEO).

Strategic objectives. The firm decided to enter Brazil because of the market potential. As the CEO puts it "Brazil is among the countries with emerging economies where the population is slowly coming to know about wine consumption: current per capita consumption is not even two litres per year yet. There is, therefore, great potential in this country for consumption to develop, and Torrevilla is investing in products aimed at this new market". Market attractiveness and the strategic objective to sell more, coupled with the 
critical partnership with an already experienced firm, led to the firm's willingness to approach the Brazilian market despite the high institutional and relatively high cultural distance.

\section{CROSS-CASE COMPARISON}

All our Brazilian and Italian firms (apart from 7-Pixel), when entering Italy and Brazil respectively, experienced a "leap" in their international growth. A closer look at Table 3 (firms' internationalisation paths) and single case analyses, shows that the processes used to approach Italy and Brazil were characterized by high perceived psychic distance (attributable to different distance dimensions, either institutional, economic, geographic), and for three cases (Dudalina, CINEX, ATOM), high commitment entry modes from the outset (instead of a gradually escalating commitment). The main finding of our study consists in our informants referring to the "leaps" as mainly driven by strategic objectives, notwithstanding the relatively high perception of distance to the target market.

Dudalina (Bra) approached Italy by establishing a showroom, having previously conducted business mainly in the US or Latin America. Despite the above-mentioned perceptions of high institutional and economic distance with the Italian market, Dudalina approached Italy mainly with the intent to gain reputation in Europe: "I can for sure say that it was a risky and tough decision to come to Italy. Customers in Italy expect a certain level of quality and they want to buy a strong brand. But we needed to enter this market if we wanted the chance to gain a reputation with customers in other European countries" (HoI). CINEX (Bra) took an even more unusual path, as the firm's first foreign country was Italy, where they established a subsidiary. The choice was dictated by the need to learn best practices embedded in a local renowned furniture cluster. Yet, as described earlier, the CEO and founder did sense high institutional (especially administrative) distance: "I worked a lot from the early start of the business to develop the best technology that we could. Hence, I decided that to do so we 
needed to leverage the best Italian expertise in this industry. Of course, this hasn't been a cheap nor an easy decision. But it had enabled us to succeed in our industry, to form a good partnership with an Italian firm, as well with a German one, and to then open opportunities in other European countries" (CEO). In a similar vein, TDV's founder - although perceiving economic distance -highlights that "the choice of Italy was due to the firm's goal of developing higher quality products and thus gaining a better positioning in the market. We had the opportunity to learn a lot in Italy because of its tradition for high quality standards in the dental industry and higher customers' expectations".

Of the Italian firms, Torrevilla's first move to Brazil came after it had approached Hong Kong (its first international market), several European countries, and China. When we asked him to talk us about the decision to approach Brazil, the CEO emphasized - although perceiving economic distance - the opportunity for selling the firm's medium-high and medium-low quality wines, but also repeatedly mentioned that he needed the support of a partner already familiar with the Brazilian market, as he perceived institutional, cultural, and economic distances "I think we made the right choice in approaching Brazil using the help provided by our partner. They had already gone there, they were more experienced than we were...I could trust them to help in any difficulties I might encounter in the market. Moreover, Brazilians do not have a wine culture, they are a completely different kind of customer".

ATOM set up a subsidiary in Brazil after having entered Europe and the US. ATOM's informant reported particularly high institutional distance, but emphasized that the decision to approach Brazil was dictated by the intent to exploit opportunities from the growing footwear market there. "Brazil was an opportunity, because in those days the footwear market was flourishing. What mattered to us was to sell our products to those customers who expected and needed excellent technology and performance quickly. It was not difficult for us to build 
a good customer base there, yet protectionist policies have been a problem for the business" (ATOM, CEO).

Of the six cases, 7-Pixel seems to have followed the most "incremental" internationalisation path, as Brazil was (wrongly) assumed by the CEO to be similar to the Spanish market, where the firm had already been successful. Unfortunately, this assumption proved to be wrong and the firm had to exit the market (see section 6.2).

Observing both individual firms' internationalisation paths and the groupings of Italian and Brazilian ventures, firm-level strategic factors, beyond objective and psychic distance, support the conceptualisation of distance as asymmetric and relative. We elaborate on this issue in the following sub-sections.

\subsection{Objective and perceived distance: distance asymmetry}

The decision to use a pair of countries enabled us to highlight asymmetry and relativity from the perspectives of objective distance measurements (country-level), managerial perceptions (individual level) of distance, and the strategic objectives pursued by the firms (firm level).

Our study reveals that distance asymmetries can also occur through "objective" factors, such as differences in regulations, institutions and markets. This first type of asymmetry identified stems from country-specific factors and is the result of protectionist measures and high artificial barriers to entry to Brazil, increasing the distance for Italian firms wishing to conduct operations there. Recently, Brazil has been implementing additional trade restrictions, marking a shift towards stricter protectionism (Barone \& Bendini, 2015). Consequently, there is asymmetry in terms of some objective country-level distance measures, which then further impacts managerial perceptions. 
Another type of asymmetry related to country-specific aspects arises from differences in the "country of origin effect". Dudalina, CINEX, and TDV all reported that they suffer from reputation issues in the European market. None of the three Italian firms in the sample perceived similar problems when they approached the Brazilian market. The Italian firms benefit from a "global" country of origin effect in a number of industries, while the Brazilians can only take advantage of a "regional" effect. This is especially evident with regards to Torrevilla (ITA) and TDV (BRA). Torrevilla can benefit from a "global country of origin effect", since the reputation for quality of Italian wine transcends national and European boarders and has global reach. In contrast, TDV only seems to benefit from a "regional country of origin effect", to the extent that its reputation spreads within the Latin American region, but not within the European continent or Italy specifically. Therefore, this firm felt that it would benefit from reputation gains as a result of its recent acquisition by a French company.

Asymmetry is also determined by managers' perceptions: this is especially the case for economic distance with special reference to characteristics of host country demand (e.g. customer preferences or purchasing power, see Hutzschenreuter et al, 2016). Although at different extents, the Brazilian and Italian respondents acknowledged relatively high economic distance. However, they at the same time indicated that demand's differences represented an opportunity for the firm's strategic objectives, amplifying the country's attractiveness. This finding is in contrast with the "psychic distance paradigm" according to which psychic distance is the main driver of internationalisation, as well as with Mitra \& Golder's (2002) finding that large economic distance between the host and the target country discourages entry to the foreign market.

We also observed asymmetries related to the perception of administrative/institutional distance, which was perceived as higher by Italian managers than by Brazilian ones. 
Nonetheless, the perception of high institutional distance was offset by the objective of pursuing strategic objectives (mainly related to market potential and sales growth).

In all, this set of findings supports the argument that strategic objectives can override psychic distance as main criterion for market selection, as predicted in process models of internationalisation.

\subsection{Distance relativity}

Distance relativity can arise from objective industry/product specific factors (Ghemawat, 2001) (industry/business level), or from individual perceptions of firms in country A about distance to country B (and the way round), and finally also from different strategic objectives of firms of the same country. With regards to the objective factors, in our sample of firms from different industries we observed that each firm reported different assessments of geographic distance, from the point of view of product/industry specificities. Some firms reported objective measures of geographic distance specific to their business, for example ATOM works with a Weight/Volume ratio of $240 \mathrm{~kg} / \mathrm{m}^{3}$ for exporting their cutting tables and Dudalina calculates taxes plus transport costs. For Torrevilla, what matters is the efficiency of cargo companies in transporting the product (wine bottles) safely, and the time taken to reach Brazilian harbours; 7-Pixel stated that they did not perceive geographical distance to be important because of the nature of its service (online engines for comparing product prices). According to CINEX's CEO their products are "excessively heavy and take up too much space to be exported to Italy". At the other end of the scale, TDV only sends a maximum of $30 \mathrm{~kg}$ of products per delivery to Italy. For this firm, geographic distance is not a direct problem: its products are very light and small, and it has had a partnership with FedEx since the early 1990s. The characteristics of its product i.e. small and lightweight, combined 
with the efficiency of the logistics system, through its partnership with FedEx, enables the firm to export all over the world without distance being an issue.

The perceptual dimension of distance relativity has also been analysed. Different decision-makers from different firms belonging to the same country have different perceptions of the distance to the same foreign market, depending on their previous experience and knowledge. For example, decision makers from Italian firms either perceived Brazil to be mildly distant in terms of culture (Torrevilla), while others did not sense critical cultural issues (ATOM, 7-Pixel).

7-Pixel's CEO initially perceived cultural and institutional distance as low during the early stages, before realizing that this was not the case. This highlights the fact that a correct approach to distance requires an alignment between perceptions and objective factors.

In relation to relativity stemming from firm-specific factors, we observed that strategic objectives play a critical role in foreign market selection, notwithstanding the abovementioned objective industry- or product-related differences. Our Brazilian firms mostly pursue the general strategic objective of entering "strategic hub" locations in Italy, seen as a "legitimizing platform" for entry to other Western European countries. Nonetheless, each firm also had specific aims for doing so.

For Dudalina, the city of Milan represents a hub for building brand reputation and positioning in the European fashion industry. From Dudalina's perspective, locating in Milan not only enabled the firm to access social capital, thanks to a local partner that helped it with penetrating local markets, understanding local regulations, or recruiting skills (Puthusserry et al, 2014), but it was also strategic from the point of view of positioning the brand in the competitive arena of its specific industry.

The same underlying strategic objectives hold in CINEX and TDV internationalisation towards Italy. The interviewees from these firms mentioned the strategic importance of Italy 
as a hub for European markets, mostly in terms of reputation building and acquisition of technological knowledge and expertise. While Dudalina focuses on Milan's potential as a fashion hub, enabling access to other (more distant) markets, CINEX set up an office in Treviso (one of the largest furniture manufacture poles in Europe) early on, in the phase of the firm's establishment, with the objective of gaining access to the technical knowledge embedded in the cluster. Right from the outset, the entrepreneur worked to develop links between Brazil and Italy to exchange technology and define market trends. The firm strengthened its partnership with Italy further still by entering into an alliance with Decoma design studio, signed in 2004, and by establishing the CINEX Lab in Treviso in 2008. In TDV's case, the strategic objective was focused on enhancing brand reputation.

On the Italian side, ATOM targeted Brazil because of the flourishing footwear industry, with little competition during the 1980s when it identified an opportunity in the growing niche market for cutting machines. Torrevilla chose Brazil because it recognized an opportunity for its sweet wines niche, to cater for the tastes of the growing middle-class market. Interestingly, Torrevilla developed a partnership (and 7-Pixel aimed to do so) to effectively manage the entry into the (distant) Brazilian market.

The literature on international entrepreneurship (Oviatt \& McDougall, 1994) and the internationalisation process support the key role of networks as a factor for enabling entry to distant market (Johanson \& Vahlne, 2009). The latter Authors discuss how distance from relevant networks and experiential learning can also occur at the network level. In our cases, when partnerships are involved, they have been part of the strategic design of the firms: they target a country for strategic reasons and then, they look for partners, not the other way round.

In 7-Pixel, the selection of Brazil as a target country was mainly driven by an assumption of similarity, as is predicted in process models (e.g. Johanson \& Vahlne, 1977), but the country was wrongly assumed to be proximate because it was perceived as similar to 
Spain in some respects. Also, the decision to manage the business remotely from Italy instead of establishing close partnerships and/or local offices/subsidiaries (the approach adopted by the other five firms) turned out to be inadequate. From this point of view - following best practices in qualitative designs (Gahuri, 2004) - 7-Pixel acts as a confirmatory case corroborating our findings, by revealing the reasons for the unsuccessful entry: a lack of alignment between objective and perceptual distance and strategic objectives, and a lack of an appropriate entry strategy. The latter, contrary to the literature on gradual commitment which supports starting via indirect or direct export, and requires progressively higher levels of commitment when the market is both distant and strategic to the firm (Zucchella \& Servais, 2012).

In conclusion, we can argue that objective dimensions, subjective perceptions of distance, and firm-specific strategic objectives contribute, at different levels, to market selection, also leading to unexpected outcomes, failures, shifts in strategy and, ultimately, to a non-deterministic internationalisation processes.

\subsection{The role of strategic objectives in bridging distance}

Comparing the evidence related to strategic objectives and the internationalisation processes of our firms, we argue that strategic objectives "override" the importance of psychic distance as a determinant of the sequence of foreign country selection.

As illustrated earlier, in the cases of Dudalina, CINEX, and TDV, Italy would not have been selected under a psychic, incremental distance logic, but was nonetheless chosen because of its strategic importance for achieving specific strategic objectives. With respect to the Italian firms, a similar conclusion can be drawn for both Torrevilla's and ATOM's choice to enter Brazil. This is, in our opinion, a critical finding because it challenges the perspective of traditional internationalisation process models (Johanson \& Vahlne, 1977). Also, the 
gradual commitment to a foreign market is not validated in our cases: according to the Uppsala model, when a market is strategic for the firm's objectives, but is characterised by significant distance, it should be approached gradually with employing initial "arm's length" modes such as export, and then higher commitment modes. However, our firms either used higher commitment modes from the outset and then established partnerships, or searched for partnerships to support market entry. In this last regard, our findings also challenge the idea that belonging to a network helps firms reach distant markets (Johanson \& Vahlne, 2009). Coviello \& Munro (1997) found that "network relationships can drive market expansion and development activities, including choice of market and entry mode.” (p.383). Coviello (2006) discusses how networks, developed before entry into a new market, even before the foundation of the firm, are instrumental to the internationalisation process.

On the other hand, our firms established partnerships which were instrumental to their strategic objectives, when they decided to enter into a market, and were not deterministically driven to a country by existing networks.

Building on the strategy based view of internationalisation whereby business strategy needs to be understood as an intrinsic part of the path to internationalisation (Andersson, 2004; Autio, 2017; Bell et al, 2004; Melin, 1992), we contend that the decision to select a given target country is taken primarily based on the firm's strategic objectives. These strategic objectives may, in fact, overcome psychic distance perceptions. Moreover, our findings suggest an apparent distance paradox: some types of distance, notably economic distance, attracts firms because they fit their strategic objectives.

Strategic objectives may be represented - as in the case of Brazilian firms - by selecting a country (Italy, in these cases) as a "strategic hub" to gain reputation and facilitate the process of positioning the brand in other Western Europe countries. The concept of hubs is not completely new in the IB literature. Some studies (Cuervo-Cazurra, 2008; Dominguez 
\& Mercier-Suissa, 2015) have already pointed out - although using different labels - the importance of hub locations in the Internationalisation process of firms. For instance CuervoCazurra (2008, p. 150), looking at Latin American MNEs in culturally sensitive products, argues that these firms "will start multinationalizing in countries that are proximate in culture, either at the level of the country or at the level of a sub-segment in the country, but are also distant in development to access higher income consumers". Similarly, Pla-Barber \& Camps (2011) talk about "springboard countries" as shortcuts to develop the necessary experiential learning needed to enter target countries, and thus reduce psychic distance. A springboard country is a "hitherto unrecognized means of acquiring the necessary experiential knowledge for breaking into a new market... [it] speeds up the entry process for MNCs in institutional environments that are very different from those of the country of origin (ibid, p. 525). However, while the springboard country standpoint may share some similariries with our concept of "strategic hubs", our notion not only encompasses the experiential learning taking place in the hub (implied in a psychic distance incremental perspective of foreign expansion) but also other strategic reasons why the firm might decide to locate in the hub, for instance, to improve its reputation. In our perspective, hub locations serve as instrumental bridges to pursue mid-long term strategic objectives.

Taken together, the evidence accumulated in our qualitative study leads us to propose the following Propositions:

Proposition 1. The selection of a given target country is influenced by a combination of objective dimensions of distance, individual perceptions of distance, and firmspecific strategic objectives.

Proposition 2. The three distance dimensions (objective, perceptual, and strategic) contribute to distance being asymmetric and relative. 
Proposition 3. The (negative) impact of objective dimensions of distance and/or of psychic distance on the likelihood of selection of a given target country is mitigated by the attractiveness (or strategic importance) of that country for the firm's strategic objectives.

Proposition 4. (High) perceived economic distance increases the positive impact of foreign market attractiveness on firm-specific strategic objectives, because it aligns with the latter.

Proposition 5. The development of partnerships and networks can follow the decision to enter a market characterised by high distance, if strategic for the firm's objectives.

In Figure 1 we propose a model, which shows how firm-specific strategic objectives have a direct effect on the selection of a given target country. Figure 1 also shows i) how foreign market attractiveness weakens the negative effect of psychic distance and objective distance dimensions on firm-specific strategic objectives; and ii) how high perceived economic distance increases the positive impact of foreign market attractiveness on firm-specific strategic objectives.

The Figure also illustrates the emergence of asymmetry and relativity when looking at firms belonging to country pairs. Firstly, objective country-specific distance dimensions determine the emergence of asymmetries, due to differences in regulations, legal frameworks etc. Secondly, asymmetries can emerge because of differences in subjective perceptions of one or more distance dimensions. Thirdly, asymmetries can emerge due to different strategic intentions (overall, the Brazilian firms internationalised to Italy to enhance their reputation, while the Italian firms mainly chose Brazil for its market potential). Lastly, firms from the same country may have different strategic objectives in selecting a given target country and thus give rise to instances of distance relativity (for Dudalina, Italy was a hub for gaining 
reputation in other European markets, while for CINEX it was strategic to upgrade competences and develop higher quality and more technologically advanced furniture).

Figure 1. A model for foreign market selection

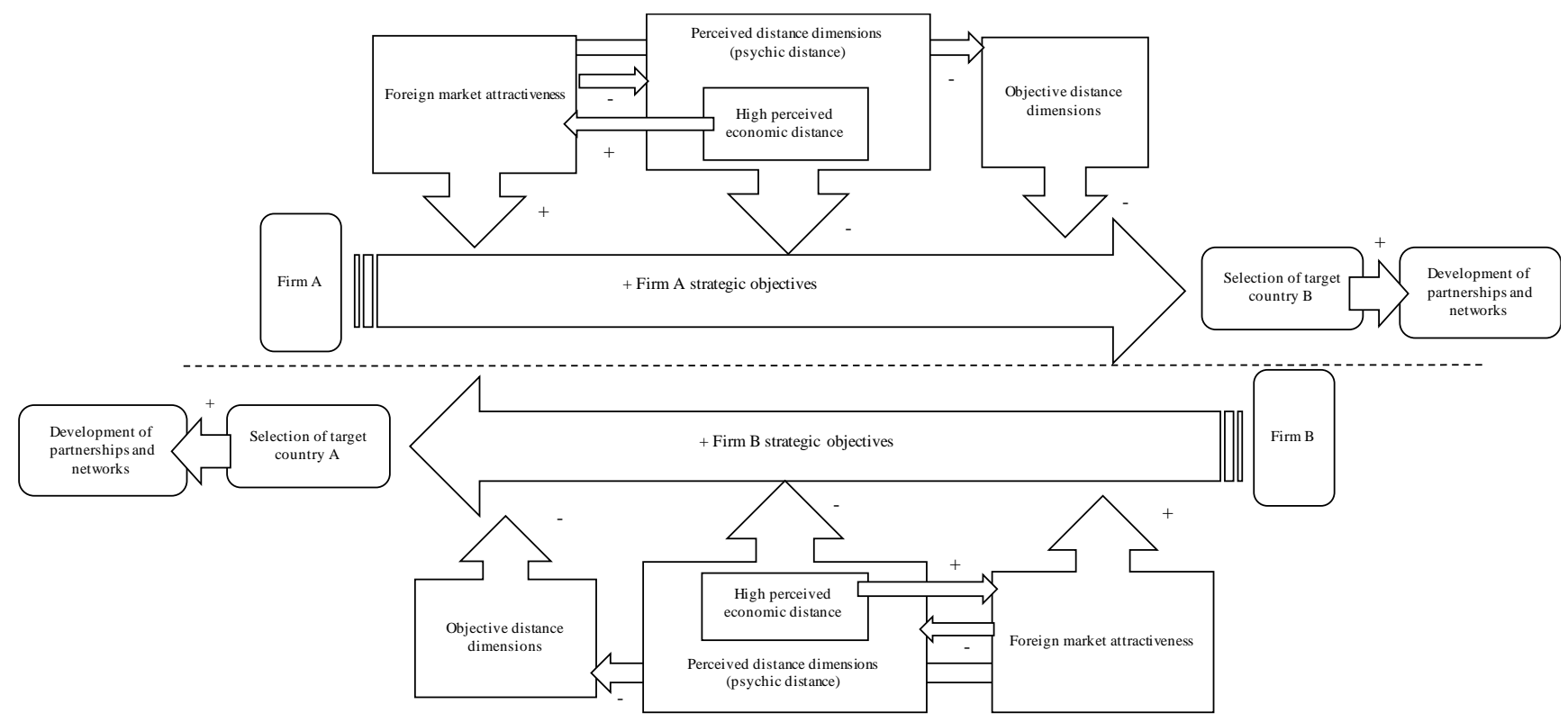

Source: The Authors 


\section{CONCLUDING REMARKS}

\subsection{Theoretical implications}

In this study, we contribute to the IB literature on distance and country selection by investigating the internationalisation decisions of three Italian and three Brazilian firms to enter Brazil and Italy, respectively. This pair of countries is characterised by a relatively high distance, both from an objective and a subjective (perceptual) point of view. The firms and their decision makers have no previous experience, either in the country targeted or in "similar" countries, and no previously existing network there. To address the complexity of this phenomenon, our theoretical framework brings together country-specific objective dimensions of distance, individual (perceived) psychic distance, and firm-specific strategic objectives.

Our study offers new theoretical insights. Overall, we provide evidence that firmspecific strategic objectives are a key variable determining the decisions to enter a foreign market. When the foreign market is distant (both from an objective and a perceptual point of view) strategic objectives counterbalance and can override psychic distance in the entry decision.

Thus, strategic objectives provide a further rationale - beyond the objective and the perceptual perspectives - for distance being asymmetric (Håkanson et al, 2016; Shenkar, 2001, 2012; Zaheer, Schomaker, \& Nachum, 2012) and relative (Beugelsdijk \& Mudambi, 2013; Håkanson \& Ambos, 2010; Goerzen, Asmussen, \& Nielsen, 2013).

We also find support to the idea that distance is highly relative to strategic objectives, because some of its dimensions (notably the economic) are not necessarily obstacles to the entry of foreign firms; on the contrary, they may be factors of attractiveness, when they fit the firms' strategic objectives. 
The key role played by strategic objectives in internationalisation decisions may explain the non-linearity of our firm's internationalisation paths: internationalisation does not necessarily start in less distant countries and proceed towards more distant ones with increasing resources commitment. These paths may be the result of a firm's market assessment in terms of its "strategic instrumentality" for prospective internationalisation plans.

In addressing the critical issue of determinism in internationalisation process models (Autio, 2017; Petersen et al., 2003), this study contributes to IB and IE studies and responds to a call for research on the role of strategy in internationalisation decisions (Autio, 2017; Bell et al, 2004, Benito, 2015; Roper \& Love, 2015). Firm-specific strategic objectives play a key role in foreign market selection and, ultimately, in shaping internationalisation paths. Our case studies also highlight the importance of strategic hubs, which offer the possibility for firms to choose locations that represent strategic points of departure for further internationalisation plans. We build on the notion of hubs stressing the strategic facet of hubs in relation to internationalisation choices.

In this vein, we also highlight the need to approach markets which are characterised by objective and perceived high distance, through an appropriate choice of an entry strategy. Low commitment modes, as the Uppsala model suggests, may not be the right answer: on the other hand, establishing local partnerships can help manage the distance better. From this point of view, we provide an additional contribution to the internationalisation process literature, which mostly refers to belonging to an (existing) network as the key to international growth (Johanson \& Vahlne, 2009; Oviatt \& McDougall, 1994). This stance is discussed in IB and IE studies, but our findings highlight that partnerships follow the decision to enter a market instead of preceding it. 
When analysing internationalisation processes in distant countries, future studies should look at target country characteristics (i.e. economic distance, including income, inflation, exports of goods and services, imports of goods and services) and at individual perceptions of distance, but they should also investigate firm-specific (subjective), mediumto-long-term strategic objectives, as well as the specific role of strategic hubs.

\subsection{Managerial implications}

This study also has implications for management practice. Our findings highlight the priority for managers to consider the relative strategic importance of markets. This is because, when considering internationalisation from a process perspective, current and future decisions to enter countries that are distant can be explained by the fact that these are hubs to access other (more) strategic markets in the future. Thus, managers should look beyond distance (Hernández \& Nieto, 2014): although the destination country may exhibit great differences from the country of origin, for instance in terms of culture, institutions, and geography, that same location may represent a crucial $h u b$ for prospective internationalisation plans.

Another relevant managerial implication is that firms needs to carefully understand the fit between objective and perceived distance. Also, distance considerations and strategic objectives need to be strongly aligned. Finally, we provide some comments on how they manage the entry into "distant" markets.

\subsection{Limitations and directions for future research}

The limitations of this study should be considered when evaluating its findings. One principal limitation is the small number of firms included. Furthermore, we only analysed two countries, therefore the findings may not be generalisable. We therefore suggest future work in this area that simultaneously analyses multiple country combinations, considering countries that are usually thought of as culturally similar and those that are not. This should increase the likelihood that the results can be generalised. 
Future studies could seek to validate our Propositions using quantitative designs, with larger samples of firms and, as mentioned, by looking at multiple pair-wise country comparisons. While this study is qualitative in nature, future quantitative designs will be needed to operationalize firm-specific strategic objectives.

Given the importance of strategic objectives to firms' internationalisation choices, longitudinal studies may well suit the objective of looking at the internationalisation process and strategic objectives in conjunction, and so more in-depth longitudinal case studies that track the process over time will be very helpful for provoking further theoretical insights.

Finally, the interweaving of multiple levels of analysis (country, individual, and firm) that appear to affect firm internationalisation decisions deserves more careful investigation by future researchers, with the objective of improving understanding of the interconnections and the underlying dynamics.

\section{REFERENCES}

Ambos, B., \& Håkanson, L. (2014). The concept of distance in international management research. Journal of International Management, 20(1), 1-7.

Andersen, O. (1997). Internationalisation and market entry mode: A review of theories and conceptual frameworks, Management International Review, 37(2), 7-42.

Andersson, S. (2004). Internationalization in different industrial contexts. Journal of Business Venturing, 19(6), 851-875.

Autio, E. (2017). Strategic entrepreneurial internationalisation: A normative framework, Strategic Entrepreneurship Journal, Accepted Author Manuscript. doi:10.1002/sej.1261.

Barkema, H. G., \& Drogendijk, R. (2007). Internationalising in small, incremental or larger steps?. Journal of International Business Studies, 38(7), 1132-1148.

Barone, B., Bendini, R. (2015). Protectionism in the G20. Directorate-General for External Policies of the Union Policy Department. Belgium: Publishing Office of the European Union. $\quad$ Retrieved from: http://www.europarl.europa.eu/RegData/etudes/STUD/2015/549028/EXPO_STU(201 5)549028_EN.pdf.

Bell, J. (1995). The internationalization of small computer software firms: A further challenge to "stage" theories. European Journal of Marketing, 29(8), 60-75.

Bell, J., Crick, D., \& Young, S. (2004). Small firm internationalization and business strategy an exploratory study of 'knowledge-intensive' and 'traditional'manufacturing firms in the UK. International Small Business Journal, 22(1), 23-56. 
Bell, B. S., \& Kozlowski, Steve W. J. (2002). A typology of virtual teams implications for effective leadership. Group \& Organization Management, 27(1), 14-49.

Benito, G. R. (2015). Why and how motives (still) matter. The Multinational Business Review, 23(1), 15-24.

Benito, G. R., \& Gripsrud, G. (1992). The expansion of foreign direct investments: Discrete rational location choices or a cultural learning process? Journal of International Business Studies. 23(3), 461-476

Berry, H., Guillén, M. F., \& Zhou, N. (2010). An institutional approach to cross-national distance. Journal of International Business Studies, 41(9), 1460-1480.

Beugelsdijk, S., \& Mudambi, R. (2013). MNEs as border-crossing multi-location enterprises: The role of discontinuities in geographic space. Journal of International Business Studies, 44(5), 413-426.

Black, J. S., \& Mendenhall, M. E. (1991). The U-curve adjustment hypothesis revisited: A review and theoretical framework. Journal of International Business Studies, 22(2), 225-247.

Brock, D. M., Shenkar, O., Shoham, A., \& Siscovick, I. C. (2008). National culture and expatriate deployment. Journal of International Business Studies, 39(8), 1293-1309.

Brouthers, K. D., \& Brouthers, L. E. (2001). Explaining the national cultural distance paradox. Journal of International Business Studies, 32(1), 177-189.

Burgelman RA. 2011. Bridging history and reductionism: A key role for longitudinal qualitative research. Journal of International Business Studies, 42(5): 591-601.

Campbell, J. T., Eden, L., \& Miller, S. R. (2012). Multinationals and corporate social responsibility in host countries: Does distance matter?. Journal of International Business Studies, 43(1), 84-106.

Cantwell, J., \& Mudambi, R. (2005). MNE competence-creating subsidiary mandates. Strategic Management Journal, 26(12), 1109-1128.

Chandler, G. N., \& Hanks, S. H. (1994). Market attractiveness, resource-based capabilities, venture strategies, and venture performance. Journal of Business Venturing, 9(4), 331349.

Chao, M. C.-H., \& Kumar, V. (2010). The impact of institutional distance on the international diversity-performance relationship. Journal of World Business, 45(1), 93-103.

Chetty, S., \& Campbell-Hunt, C. (2004). A strategic approach to internationalization: A traditional versus a "born-global" approach. Journal of International Marketing, 12(1), 57-81.

Child, J., Rodrigues, S. B., \& Frynas, J. G. (2009). Psychic distance, its impact and coping modes. Management International Review, 49(2), 199-224.

Clark, X., Dollar, D., \& Micco, A. (2004). Port efficiency, maritime transport costs, and bilateral trade. Journal of Development Economics, 75(2), 417-450.

Combes, P.-P., \& Lafourcade, M. (2005). Transport costs: measures, determinants, and regional policy implications for France. Journal of Economic Geography, 5(3), 319349.

Coviello, N. E. (2006). The network dynamics of international new ventures. Journal of international Business Studies, 37(5), 713-731. 
Coviello, N., \& Munro, H. (1997). Network relationships and the internationalisation process of small software firms. International Business Review, 6(4), 361-386.

Cuervo-Cazurra, A. (2008). The multinationalization of developing country MNEs: The case of multilatinas. Journal of international Management, 14(2), 138-154.

Cuervo-Cazurra, A., \& Genc, M. (2008). Transforming disadvantages into advantages: Developing-country MNEs in the least developed countries. Journal of international Business Studies, 39(6), 957-979.

Cuervo-Cazurra, A., Narula, R., \& Un, C. A. (2015). Internationalization motives: Sell more, buy better, upgrade and escape. The Multinational Business Review, 23(1), 25-35.

Cui, A. P., Walsh, M. F., \& Zou, S. (2014). The importance of strategic fit between hosthome country similarity and exploration exploitation strategies on small and mediumsized enterprises' performance: A contingency perspective. Journal of International Marketing, 22(4), 67-85.

D’Angelo, A., Majocchi, A., Zucchella, A., \& Buck, T. (2013). Geographical pathways for SME internationalization: Insights from an Italian sample. International Marketing Review, 30(2), 80-105.

Dichtl, E., Leibold, M., Köglmayr, H.-G., \& Mueller, S. (1984). The export-decision of small and medium-sized firms: A review. Management International Review, 24(2), 49-60.

Dheer, R. J., Lenartowicz, T., \& Peterson, M. F. (2015). Mapping India's regional subcultures: Implications for international management. Journal of International Business Studies, 46(4), 443-467.

Dominguez, N., \& Mayrhofer, U. (2017). Internationalization stages of traditional SMEs: Increasing, decreasing and re-increasing commitment to foreign markets. International Business Review, In press. DOI: https://doi.org/10.1016/j.ibusrev.2017.03.010.

Dominguez, N., \& Mercier-Suissa, C. (2015). Investing in a gateway country: A small French company implanted in Finland for access to Russia. Revue d'etudes comparatives estouest, 46(3), 183-210.

Dow, D. (2000). A note on psychological distance and export market selection. Journal of International Marketing, 8(1), 51-64.

Dow, D., \& Karunaratna, A. (2006). Developing a multidimensional instrument to measure psychic distance stimuli. Journal of International Business Studies, 37(5), 578-602.

Dow, D., \& Larimo, J. (2009). Challenging the conceptualization and measurement of distance and international experience in entry mode choice research. Journal of International Marketing, 17(2), 74-98.

Drogendijk, R., \& Martín, O. M. (2015). Relevant dimensions and contextual weights of distance in international business decisions: Evidence from Spanish and Chinese outward FDI. International Business Review, 24(1), 133-147.

Dubois, A., \& Gadde, L.-E. (2002). Systematic combining: An abductive approach to case research. Journal of Business Research, 55(7), 553-560.

Dunning, J. H. (1998). Location and the multinational enterprise: A neglected factor? Journal of International BusinessStudies, 29(1), 45-66.

Eden, L., \& Miller, S. R. (2004). Distance matters: Liability of foreignness, institutional distance and ownership strategy. In M. Hitt \& J. Cheng (Eds.), Advances in International Management (pp. 187-221). New York: Elsevier. 
Edwards, R. W., \& Buckley, P. J. (1998). Choice of location and mode: The case of Australian investors in the UK. International Business Review, 7(5), 503-520.

Eisenhardt, K. M. (1989). Building theories from case study research. Academy of Management Review, 14(4), 532-550.

Eisenhardt, K. M., \& Graebner, M. E. (2007). Theory building from cases: Opportunities and challenges. Academy of Management Journal, 50(1), 25-32.

Ellis, P. D. (2007). Paths to foreign markets: Does distance to market affect firm internationalization?. International Business Review, 16(5), 573-593.

Ellis, P. D. (2008). Does psychic distance moderate the market size-entry sequence relationship?. Journal of International Business Studies, 39(3), 351-369.

Eriksson, K., Majkgard, A., \& Sharma, D. D. (2000). Path Dependence and knowledge development in the internationalization process. Management International Review, 40(4), 307-307.

Erramilli, M. K., \& Rao, C. (1990). Choice of foreign market entry modes by service firms: Role of market knowledge. Management International Review, 30(2), 135-150.

Eurostat (2016). The EU in the world - 2016 edition. Luxembourg: Publications Office of the European Union. Retrieved from http://ec.europa.eu/eurostat/documents/3217494/7589036/KS-EX-16-001-EN-N.pdf.

Evans, J., \& Mavondo, F. T. (2002). Psychic distance and organizational performance: An empirical examination of international retailing operations. Journal of International Business Studies, 33(3), 515-532.

Factbook, C.I.A. (2012). The CIA world factbook2012. Retrieved from C.I.A. website: https://www.cia.gov/library/publications/download/download-2012/.

Ferner, A., Almond, P., \& Colling, T. (2005). Institutional theory and the cross-national transfer of employment policy: The case of 'workforce diversity'in US multinationals. Journal of International Business Studies, 36(3), 304-321.

Fleury, A. \& Fleury, M.T.L (2011) Brazilian multinationals: Competences for internationalization. Cambridge, UK: Cambridge University Press, 2011.

Frankel, J., \& Rose, A. (2002). An estimate of the effect of common currencies on trade and income. Quarterly Journal of Economics, 117(2), 437-466.

Garnsey, E., Stam, E., \& Heffernan, P. (2006). New firm growth: Exploring processes and paths. Industry and Innovation, 13(1), 1-20.

Ghauri, P. N., (2004). Designing and conducting case studies in international business research, in Marschan-Piekkari, Welch, C. (Eds.), Handbook of qualitative research methods for international business, Cheltenham: Edward Elgar, pp. 109-124.

Ghauri, P., \& Grønhaug, K. (2002). Research methods in business studies. Harlow: Financial Times.

Ghemawat, P. (2001). Distance still matters. Harvard Business Review, 79(8), 137-147.

Glaser, B., \& Strauss, A. (1967). The discovery of grounded theory. London: Weidenfield \& Nicolson.

Goerzen, A., Asmussen, C. G., \& Nielsen, B. B. (2013). Global cities and multinational enterprise location strategy. Journal of International Business Studies, 44(5), 427-450.

Grant, R. M. (1987). Multinationality and Performance among British Manufacturing Companies. Journal of International Business Studies, 18(3), 79-89. 
Grosse, R., \& Trevino, L. J. (1996). Foreign Direct Investment in the United States: An Analysis by Country of Origin. Journal of International Business Studies, 27(1), 139155.

Håkanson, L., \& Ambos, B. (2010). The antecedents of psychic distance. Journal of International Management, 16(3), 195-210.

Håkanson, L., Ambos, B., Schuster, A., \& Leicht-Deobald, U. (2016). The psychology of psychic distance: Antecedents of asymmetric perceptions. Journal of World Business, 51(2), 308-318.

Hennart, J. F. (2012). Emerging market multinationals and the theory of the multinational enterprise. Global Strategy Journal, 2(3), 168-187.

Hernández, V., \& Nieto, M. J. (2014). The effect of the magnitude and direction of institutional distance on the choice of international entry modes. Journal of World Business 50(1), 122-132.

Hinds, P. J., \& Bailey, D. E. (2003). Out of sight, out of sync: Understanding conflict in distributed teams. Organization Science, 14(6), 615-632.

Hofstede, G. (1980). Culture's consequences. Beverly Hills, CA: Sage.

Hofstede, G. (1983). The cultural relativity of organizational practices and theories. Journal of International Business Studies, 14(2), 75-89.

Hummels, D. (2001). Toward a geography of trade costs. Purdue University: Mimeo

Hutzschenreuter, T., Pedersen, T., \& Volberda, H. W. (2007). The role of path dependency and managerial intentionality: A perspective on international business research. Journal of International Business Studies, 38(7), 1055-1068.

Hutzschenreuter, T., Kleindienst, I., \& Lange, S. (2014). Added psychic distance stimuli and MNE performance: Performance effects of added cultural, governance, geographic, and economic distance in MNEs' international expansion. Journal of International Management, 20(1), 38-54.

Hutzschenreuter, T., Kleindienst, I., \& Lange, S. (2016). The concept of distance in international business research: A review and research agenda. International Journal of Management Reviews, 18(2), 160-179

Hymer, S. H. (1976). The international operations of national firms: A study of foreign direct investment. Cambridge, MA: MIT Press.

ICE (2013). Italy in the World economy. Summary of the ICE report for 2012-2013. Retrieved from Italtrade website: http://www.italtrade.com/italy/ice_report2013_summary.pdf.

ICE (2014). Sintesi del rapporto ICE 2013-2014. L'Italia nell'economia nazionale. Retrieved from ICE website: http://www.ice.it/statistiche/pdf/sintesi_ice.pdf.

Jick, T. D. (1979). Mixing qualitative and quantitative methods: Triangulation in action. Administrative Science Quarterly, 24(4), 602-611.

Johanson, J., \& Vahlne, J.-E. (1977). The internationalization process of the firm-a model of knowledge development and increasing foreign market commitments. Journal of International Business Studies, 8(1), 23-32.

Johanson, J., \& Vahlne, J.-E. (1990). The mechanism of internationalization. International Marketing Review, 7(4), 11-24. 
Johanson, J., \& Vahlne, J.-E. (2009). The Uppsala internationalization process model revisited: From liability of foreignness to liability of outsidership. Journal of International Business Studies, 40(9), 1411-1431.

Johanson, J., \& Wiedersheim-Paul, F. (1975). The internationalization of the firm-four Swedish cases. Journal of Management Studies, 12(3), 305-323.

Kaufmann, D., Kraay, A., \& Mastruzzi, M. (2009). Governance matters VIII: Aggregate and individual governance indicators, 1996-2008. World bank policy research working paper, (4978).

Kirkman, B. L., Lowe, K. B., \& Gibson, C. B. (2006). A quarter century of culture's consequences: A review of empirical research incorporating Hofstede's cultural values framework. Journal of International Business Studies, 37(3), 285-320.

Knight, G. A., \& Liesch, P. W. (2016). Internationalization: From incremental to born global. Journal of World Business,51(1), 93-102.

Kogut, B., \& Singh, H. (1988). The effect of national culture on the choice of entry mode. Journal of International Business Studies, 19(fall), 411-432.

KPMG (2013). Modello di sviluppo industriale nel sistema Italia in Brasile. Terza edizione.

Executive summary. Retrieved online from Ministero degli Esteri website: http://www.esteri.it/mae/approfondimenti/20131025_ebook_summary_settembre.pdf

Leamer, E. E. (1974). The commodity composition of international trade in manufactures: An empirical analysis. Oxford Economic Papers, 26(3), 350-374.

Limao, N., \& Venables, A. J. (2001). Infrastructure, geographical disadvantage, transport costs, and trade. The World Bank Economic Review, 15(3), 451-479.

Love, J. H., \& Roper, S. (2015). SME innovation, exporting and growth: A review of existing evidence. International Small Business Journal, 33(1), 28-48.

Luo, Y., \& Tung, R. L. (2007). International expansion of emerging market enterprises: A springboard perspective. Journal of International Business Studies, 38(4), 481-498.

Malhotra, S., Sivakumar, K., \& Zhu, P. (2009). Distance factors and target market selection: The moderating effect of market potential. International Marketing Review, 26(6), 651-673.

Manev, I. M., \& Stevenson, W. B. (2001). Balancing ties: Boundary spanning and influence in the organization's extended network of communication. Journal of Business Communication, 38(2), 183-205.

Melin, L. (1992). Internationalization as a strategy process. Strategic Management Journal, 13(S2), 99-118.

Meyer, K. E., Estrin, S., Bhaumik, S. K., \& Peng, M. W. (2009). Institutions, resources, and entry strategies in emerging economies. Strategic Management Journal, 30(1), 61-80.

Meyer, K. E. (2015). What is "strategic asset seeking FDI"?. The Multinational Business Review, 23(1), 57-66.

Mitra, D., \& Golder, P. N. (2002). Whose culture matters? Near-market knowledge and its impact on foreign market entry timing. Journal of Marketing Research, 39(3), 350365.

Morosini, P., \& Singh, H. (1994). Post-cross-border acquisitions: Implementing 'national culture-compatible' strategies to improve performance. European Management Journal, 12(4), 390-400. 
Nebus, J., \& Chai, K. H. (2014). Putting the "psychic" back in psychic distance: Awareness, perceptions, and understanding as dimensions of psychic distance. Journal of International Management, 20(1), 8-24.

OECD (2013). OECD Economic Surveys: Brazil 2013. OECD Publishing. Retrieved from OECD website: http://www.oecd-ilibrary.org/economics/oecd-economic-surveysbrazil-2013_eco_surveys-bra-2013-en.

OECD (2015). OECD Economic Surveys: Brazil 2015. OECD Publishing. Retrieved from OECD website: http://www.oecd-ilibrary.org/economics/oecd-economic-surveysbrazil_19990820;jsessionid=bghaktfehlp8q.X-oecd-live-03.

Ojala, A. (2015). Geographic, cultural, and psychic distance to foreign markets in the context of small and new ventures. International Business Review, 24(5), 825-835.

Oviatt, B. M., \& McDougall, P. P. (1994). Toward a theory of international new ventures. Journal of International Business Studies, 25(1), 45-64.

Patton, M. Q. (1990). Qualitative evaluation and research methods (2nd ed). Newbury, CA: Sage.

Pedersen, T., \& Petersen, B. (2004). Learning about foreign markets: Are entrant firms exposed to a "shock effect"? Journal of International Marketing, 12(1), 103-123.

Petersen, B., Pedersen, T., \& Sharma, D. D. (2003). The role of knowledge in firms' internationalisation process: Wherefrom and whereto? In A. Blomstermo \& D. D. Sharma (Eds), Learning in the internationalisation process of firms: 36-55. Cheltenham: Edward Elgar.

Pla-Barber, J., \& Camps, J. (2011). Springboarding: A new geographical landscape for European foreign investment in Latin America.Journal of Economic Geography, 12(2), 519-538.

Puthusserry, P. N., Child, J., \& Rodrigues, S. B. (2014). Psychic distance, its business impact and modes of coping: A study of British and Indian partner SMEs. Management International Review, 54(1), 1-29.

Ramamurti, R. (2012). What is really different about emerging market multinationals?. Global Strategy Journal, 2(1), 41-47.

Robertson, K. R., \& Wood, V. R. (2001). The relative importance of types of information in the foreign market selection process. International Business Review, 10(3), 363-379.

Rugman, A. M., Verbeke, A., \& Nguyen, Q. T. (2011). Fifty years of international business theory and beyond. Management International Review, 51(6), 755-786.

Sakarya, S., Eckman, M., \& Hyllegard, K. H. (2007). Market selection for international expansion: Assessing opportunities in emerging markets. International Marketing Review, 24(2), 208-238.

Schmitt, A., \& Van Biesebroeck, J. (2013). Proximity strategies in outsourcing relations: The role of geographical, cultural and relational proximity in the European automotive industry. Journal of International Business Studies, 44(5), 475-503.

Shenkar, O. (2001). Cultural distance revisited: Towards a more rigorous conceptualization and measurement of cultural differences. Journal of International Business Studies, $32(3), 519-535$.

Shenkar, O. (2012). Beyond cultural distance: Switching to a friction lens in the study of cultural differences. Journal of International Business Studies, 43(1), 12-17. 
Shenkar, O., Luo, Y., \& Yeheskel, O. (2008). From "distance" to "friction": Substituting metaphors and redirecting intercultural research. Academy of Management Review, 33(4), 905-923.

Slangen, A. H., \& Beugelsdijk, S. (2010). The impact of institutional hazards on foreign multinational activity: A contingency perspective. Journal of International Business Studies, 41(6), 980-995.

Sousa, C. M., \& Bradley, F. (2006). Cultural distance and psychic distance: Two peas in a pod? Journal of International Marketing, 14(1), 49-70.

Stöttinger, B., \& Schlegelmilch, B. B. (1998). Explaining export development through psychic distance: Enlightening or elusive? International Marketing Review, 15(5), 357-372.

Terjesen, S., Hessels, J., \& Li, D. (2016). Comparative international entrepreneurship: A review and research agenda. Journal of Management, 42(1), 299-344.

Tung, R. L., \& Verbeke, A. (2010). Beyond Hofstede and GLOBE: Improving the quality of cross-cultural research. Journal of International Business Studies, 41(8), 1259-1274.

UNCTAD (2015). World Investment Report 2015 (Report No. 25). Reforming international investment governance. Geneva, Switzerland: United Nations Publication. Retrieved from UNCTAD website: http://unctad.org/en/PublicationsLibrary/wir2014_en.pdf.

van Tulder, R. (2015). Getting all motives right: A holistic approach to internationalization motives of companies. The Multinational Business Review, 23(1), 36-56.

Verwaal, E., \& Donkers, B. (2003). Customs-related transaction costs, firm size and international trade intensity. Small Business Economics, 21(3), 257-271.

Volberda, H. W., \& Lewin, A. Y. (2003). Co-evolutionary dynamics within and between firms: From evolution to co-evolution. Journal of Management Studies, 40(8), 21112136.

Williams, D. W., \& Grégoire, D. A. (2014). Seeking commonalities or avoiding differences [quest] Re-conceptualizing distance and its effects on internationalization decisions. Journal of International Business Studies, 46(3), 253-284.

World Bank (2015a). World development indicators: Brazil data [World Development Indicators database]. Retrieved from World Bank website: http://data.worldbank.org/country/brazil

World Bank (2015b). World development indicators: Italy data [World Development Indicators database]. Retrieved from World Bank website: http://data.worldbank.org/country/italy

World Bank (2016). World development indicators database: Brazil data [World Development Indicators database]. Retrieved from http://databank.worldbank.org/data/download/GDP.pdf.

Yamin, M., \& Sinkovics, R. R. (2006). Online internationalisation, psychic distance reduction and the virtuality trap. International Business Review, 15(4), 339-360.

Yildiz, H. E. (2014). Not all differences are the same: Dual roles of status and cultural distance in sociocultural integration in cross-border M\&As. Journal of International Management, 20(1), 25-37.

Yin, R. K. (1994). Case study research. Design and methods. Thousand Oaks: Sage. 
Zahra, S. A., Matherne, B. P., \& Carleton, J. M. (2003). Technological resource leveraging and the internationalisation of new ventures. Journal of International Entrepreneurship, 1(2), 163-186.

Zaheer, S. (1995). Overcoming the liability of foreignness. Academy of Management Journal, 38(2), 341-363.

Zaheer, S., Schomaker, M. S., \& Nachum, L. (2012). Distance without direction: Restoring credibility to a much-loved construct. Journal of International Business Studies, 43(1), 18-27.

Zucchella, A., \& Servais, P. (2012). The internationalisation process of small and mediumsized firms and the liability of complexity. International Journal of Entrepreneurship and Small Business, 15(2), 191-212. 